\title{
Phaselis Teritoryumunda Tespit Edilen Lahitlerin RTI Metodu Işığında Arkeolojik ve Epigrafik İncelemeleri
}

\author{
Archaeological and Epigraphical RTI Analysis of the Sarcophagi \\ found in the Territory of Phaselis
}

\author{
N. TÜNER ÖNEN ${ }^{*}-$ B. GÜREL $L^{* *}-A$. AKÇAY $Y^{* * *}$
}

\begin{abstract}
Öz: Bu makalenin amacı 2015-2017 yılları arasında Phaselis ve teritoryumunda yürütülen yüzey araştırmaları kapsamında, kentin teritoryum sınırları içerisinde bulunan Tahtalı Dağ'ın kuzeyinde konumlanan Beşiktaş mevkii ile Teke Dağ’ın doğu eteklerindeki Yaylakuzdere ve Çürük Dağ’ın batısındaki Üçoluk Yaylası Kırtepe mevkilerinde tespit edilen üç lahit mezar ve bir lahit kapağının yeni sayısal belgeleme metotlarından RTı teknolojisi kullanılarak epigrafik ve arkeolojik olarak değerlendirilmesidir. Söz konusu lahit mezarların üçü podyumlu olup, oldukça iyi korunmuş durumdadırlar ve lahit tekneleri zengin motiflerle bezenmiştir. Beşiktaş mevkiindeki lahit ile Kırtepe mevkiindeki lahit mezarlardan biri üzerinde mezar yazııı tespit edilebilmiştir. Yaylakuzdere'de bulunan mezarın ise, teknesi oldukça tahrip edilmiştir. Bu sebeple burada sadece semerdam kapak üzerindeki mezar yazııı değerlendirilmeye alınmıştır. Söz konusu mezarların dördü de hem arkeolojik hem de epigrafik açıdan değerlendirilmiş ve Roma Imparatorluk Dönemi'ne tarihlendirilmiştir. Phaselis teritoryumunda böylesi görkemli mezarların bulunması, bölgenin söz konusu dönemdeki ekonomik refahına ve entelektüel birikimine işaret etmektedir.
\end{abstract}

Anahtar sözcükler: Phaselis, Lahit, Arkeoloji, Epigrafi, Mezar Yazıtı, RTI

Abstract: This article aims an epigraphical and archaeological analysis of three sarcophagi and a sarcophagus' lid found within the scope of surface surveys carried out in Phaselis and its territory between 2015-2017, and located in Beşiktaş location on the northern side of Mt. Tahtalı, in Yaylakuzdere on the eastern slopes of Mt. Teke, and Üçoluk Yaylası Kırtepe location on the western slope of Mt. Çürük, by using a computational photography method called Reflectance Transformation Imaging (RTI). The three sarcophagi aforesaid have platforms, and are in good situation. Each of them are well decorated. Two epitaphs are found on the sarcophagi, one in Beşiktaş loction and the other in Kırtepe location. The basin of the sarcophagus located in Yaylakuzdere is highly ravaged, that's why this article includes only the epitaph carved on the gable-roofed lid. The four sarcophagi aforesaid are archaeologically and epigraphically dated to Roman Imperial Period. The presence of these high standart sarcophagi is a sign for the region's economic welfare and intellectual development in the period aforesaid.

Keywords: Phaselis, Sarcophagus, Archaeology, Epigraphy, Epitaph, RTI

\footnotetext{
Doç. Dr., Akdeniz Üniversitesi, Edebiyat Fakültesi, Eskiçağ Dilleri ve Kültürleri Bölümü, Antalya, nihaltuner@akdeniz.edu.tr

** Arş. Gör., Akdeniz Üniversitesi, Akdeniz Uygarlıkları Araştırma Enstitüsü, Akdeniz Eskiçağ Araştırmaları ABD., Antalya, betulgurel@akdeniz.edu.tr

Arş. Gör., Akdeniz Üniversitesi, Akdeniz Uygarlıkları Araştırma Enstitüsü, Akdeniz Eskiçağ Araştırmaları ABD., Antalya, aykanakcay@akdeniz.edu.tr
} 


\section{Giriş}

Makalede, Phaselis ve Teritoryumu Yüzey Araştırmaları ${ }^{1}$ kapsamında 2015-2017 yılları arasında teritoryumda yürütülen çalışmaları sırasında Tahtalı Dağ'ın kuzeyinde konumlanan Beşiktaş mevkii ile Teke Dağ'ın doğu eteklerinde yer alan Yaylakuzdere ve Çürük Dağ'ın batı eteğinde bulunan Üçoluk Yaylası, Kırtepe mevkiinde tespit edilen üç lahit mezar ve bir lahit kapağı yeni sayısal belgeleme metotlarından RTI teknolojisi kullanılarak arkeolojik ve epigrafik olarak değerlendirilmektedir. Eserlere temas etmeksizin 'tahribatsı' belgelemeye ve çok yönlü analize imkan veren RTI metodu yardımıyla lahitler üzerinde tarhibatsız belgeleme çalışması yürütülmüştür.

Açık hava koşullarında uzun yıllar doğal ve beşeri şartlara maruz kalan arkeolojik eserlerin yüzeylerinde gözlemlenen aşınmalar, geçmişe dair barındırdıkları verilerin deformasyona uğramasına sebep olabilmektedir. Eserler üzerindeki ayrıntıların görsel olarak doğru algılanmasını olumsuz etkileyen bu durum söz konusu malzemelerin bilinen belgeleme yöntemleriyle çözümlenmesini zorlaştırmaktadır. Buradaki çalışmaya dahil edilen eserlerde de insan kaynaklı tahribatın yanı sıra, özellikle kireçtaşı, mermer ve kumtaşından lahitlerin yüzeyinde oluşan likenler ve siyah mikromantarların aşınmalara sebep olduğu ve bunların oluşturduğu mekanik etkilerin görsel algıyı zayıflattığı gözlemlenmektedir².

RTI metodunun arkeolojik ve epigrafik verilerin analiz sürecine sunduğu pozitif katkıyı ele almayı amaçlayan söz konusu çalışmanın en önemli hedefini ise, eserler üzerindeki tahribatın her geçen gün çeşitli sebeplerle devam etmesi göz önünde bulundurulduğunda, Phaselis teritoryumu lahitleri özelinde, kültür mirasımızın tamamen yok olmadan sayısal olarak belgelenmesi, arşivlenmesi ve gelecek nesillere aktarılması oluşturmaktadır.

\section{Metot: Reflectance Transformation Imaging}

Reflectance Transformation Imaging (RTI = Yansıtma Dönüşümlü Görüntüleme), bir nesne yüzeyinin farklı noktalardan aydınlatılmasıyla elde edilen yansıtma değerlerinin sentezlenmesi sonucu hassas yüzey modelinin oluşturulmasını sağlayan sayısal bir fotoğraflama metodudur ${ }^{3}$. RTI metodunun altyapısını oluşturan PTM teknolojisi ilk olarak 2001 yılında tanıtılmıs ve bir arkeolojik materyal üzerinde uygulanarak bilinen yöntemlerle görülemeyen detayların ortaya çıkmasını sağlamıştır ${ }^{4}$. Kültürel miras araştırmalarında birçok alanda uygulanan metodun arkeoloji özelinde kullanımına bakıldığında epigrafi ${ }^{5}$, nümizmatik ${ }^{6}$, seramik ${ }^{7}$, ve kaya sanatı ${ }^{8}$ etc. gibi disiplinlerde materyal kültür kalıntılarının analiz sürecine katkı sağlayan bir metot olarak çalışmalara dahil edildiği görülmektedir.

RTI görüntüleri, statik durumda bulunan bir fotoğraf makinesi kullanılarak, nesne yüzeyinin

1 Phaselis Antik Kenti ve Teritoryumu'nda 2012 yılından itibaren devam eden araştırmalar hakkında detaylı bilgi için bk. Arslan - Tüner Önen 2016a, 355-368; 2016b, 300 vdd; 2017, 213-223. Ayrıca bk. Phaselis Araştırmaları resmi web sitesi: www.phaselis.org

2 Arkeolojik eserler üzerinde meydana gelen fungal korozyonla ilgili detaylı bilgi için bk. H. Sert - F. Akdeniz 2017, 73-80.

Mudge et al. 2006, 196.

Malzbender et al. 2000.

Kleinitz 2012; Kleinitz 2013; Piquette 2014; Tüner Önen - Akçay 2014; Akçay 2016.

Mudge et al. 2005; Palma et al. 2012.

Earl et al. 2011.

8 Mudge et al. 2006; Duffy 2010; Kleinitz 2012; Mudge et al. 2012; Frood - Howley 2014; Hameeuw et al. 2016; Diaz-Guardamino - Wheatley 2013; Díaz-Guardamino et al. 2015. 
yarım küre formunda farkıı açıardan aydınlatılması ile kaydedilen görüntü dizisinden oluşmaktadır. RTI verisini oluşturabilmek için, her bir görüntüde ışığın nesne yüzeyine geliş yönü bilinmek zorundadır. Bu gereksinim için kullanılan iki farklı kayıt yöntemi bulunmaktadır.

Bunlardan ilki, kubbe formunda bir strüktürün tepe noktasına yerleştirilen fotoğraf makinesi ve konumları bilinen LED ışıklardan oluşturulan Dome-RTI sistemidir ${ }^{9}$. Otomatik çekim yapabilmesi sayesinde kısa sürede RTI verisi sunabilmesine karşın boyut kısıtlaması, maliyet ve taşınabilirlik gibi faktörler nedeniyle Dome-RTI küçük ölçekli arkeolojik eserlerin kaydı için uygundur ${ }^{10}$.

Diğer kayıt yöntemi ise çalışmamızdaki lahitlerin belgelenmesinde uyguladığımız Highlight-RTı metodudur $^{11}$. H-RTI taşınabilir ekipmanlarla (fotoğraf makinesi, paraflaş, tripod etc.) arazi koşullarında RTI kaydına imkan veren mobil bir sistemdir. Dome metoduna göre daha esnek olan H-RTI ile arazi çalışmalarında tespit edilen gerek küçük gerekse büyük ölçekli materyal kültür kalıntılarının kaydını yapmak mümkündür. H-RTI kaydı boyunca nesne ve fotoğraf makinesinin sabit kalması sağlanırken, nesne yüzeyi yarım küre formunda bir ışık dağılımı uygulanarak aydınlatıımaktadır. Işık konumları sahneye yerleştirilen yansıtıı küreler yardımıyla RTI oluşturma yazııımında ${ }^{12}$ otomatik olarak tespit edilmektedir. Her bir görüntüdeki yansıtma değerleri piksel başına hesaplanarak nesnenin yüzey topografyasına ait sayısal bir yüzey modeli oluşturulmaktadır ${ }^{13}$. RTI görüntüleme programında ${ }^{14}$ nesnelerin sayısal kopyasının yüzeyi istenilen açıdan aydınlatılabilmektedir. Bununla birlikte görsel algıуı önemli ölçüde artıran matematiksel görüntüleme filtreleri yüzeye uygulanarak eserlerin detaylı bir analiz sürecinden geçirilmesi mümkün hale gelmektedir. Bu filtreler yardımıyla özellikle yüzeyi yıpranmış arkeolojik materyallerin bardındırdığı verilere dair çok yönlü analiz süreci yürütülmekte ve alanda kullanılagelen geleneksel metotlarla ya da direkt gözlemle görülemeyen detaylar açığa çıkarılmaktadır.

\section{Lahitler Üzerinde H-RTI Metodunun Uygulanması: Karşılaşılan Zorluklar ve Çözümler}

H-RTI metodu, taşınabilir ekipmanlarla uzak lokasyonlarda bulunan kültür varlıklarının doğru, hassas bir şekilde belgelenmesine imkan vermektedir. Bununla birlikte çalışmamızda irdelenen lahitlerin RTI kurulumu ve kaydı sırasında, arazi koşulları sebebiyle ortaya çeşitli kısıtlamalar ve zorluklar çıkmıştır. Kaydı yapılan materyalin bulunduğu lokasyonda, dış ortam koşullarıyla birlikte ortaya çıkan güneş, rüzgar ve engebeli arazi etc. gibi farklı unsurlar kayıt olanaklarını zorlaştırabilmektedir. Bu noktada eserlerin hassas ve doğru bir H-RTI kaydını elde edebilmek için arazi koşullarına ön hazırlık yapmak ve doğru ekipman seçimi ön plana çıkmaktadır. Lahitler üzerinde gerçekleştirdiğimiz H-RTI çalışmaları, araştırma döneminin kapsadığı yaz aylarında yürütüldüğü için Akdeniz Bölgesi'nin kuvvetli güneş ışınlarının üstesinden gelebilecek bir paraflaş (500Ws) tercih edilmiştir. Zira H-RTı kaydı boyunca ışık kaynağı, lahdin yüzeyine belirli bir mesafeden ${ }^{15}$ uygulanmalı

\footnotetext{
Dome-RTI hakkında detaylı bilgi için bk. Malzbender 2001; Willems 2005.

Zanyi et al. 2007, 4.

1 Mudge et al. 2006.

12 RTI Builder ve RTI Viewer açık kaynaklı yazılımlar olup ücretsiz erişime açıktır. (http://culturalheritageimaging. org/what_we_offer/downloads).

13 Barbosa 2009, 58.

14 Mudge et al. 2006.

15 H-RTI kaydı sırasında nesne yüzeyi farklı açılardan aydınlatılırken nesne-ışık mesafesinin sabit kalması ger-
} 
ve eserin yüzeyi tamamen aydınlatılabilmelidir. Buna ek olarak ışınların en kuvvetli olduğu zaman diliminde yapılan kayıtlarda -öğle saatlerinde- doğal yoğunluk filtresi (ND, 2-8 f/stop) kullanılmış ve eserlerin renk ve ton ayarları etkilenmeden, ısı̆̆ın absorbe edilmesi sağlanmıştır. Ayrıca fotoğraf kaydı sırasında kablosuz tetikleyici kullanılarak makineye temas edilmeksizin statik bir görüntü dizisi elde edilmiştir. Son olarak lahitlerin bulunduğu lokasyonlarda (1000-1200 m) muhtemel rüzgarlara karşı dayanıklı ve engebeli zemine uyum sağlayabilen profesyonel bir üçayak (tripod) ve yardımcı kollar kullanıımıştır. Zira kayıt sırasında ışık kaynağı haricinde tüm ekipmanın ve nesnenin sabit kalması gerekmektedir. Aksi takdirde nesnenin veya kameranın 1 mm'lik bir oynamaya dahi maruz kalması yüzeyi bulanık, orijinaliyle örtüşmeyen bir sayısal kopyanın oluşmasına sebep olacaktır.

2016 yılı Phaselis Teritoryum çalışmaları kapsamında Beşiktaş mevkiinde oldukça zengin kabartmalar barındıran bir lahit mezar tespit edilmiştir (Fig 1). Söz konusu lahdin yüzeyinde gerek tabula kısmında bulunan yazıtta gerekse plastik kabartmalarında deformasyon gözlemlenmiştir. Yüzeyde görülen doğal aşınmayla birlikte liken ve mantarların da sebep olduğu tahribat, lahdin barındırdığı arkeolojik verilerin, yerinde direkt analizle veya fotoğraf üzerinden değerlendirilmesini güç hale getirmektedir. Bu durum nedeniyle lahdin H-RTI kaydı yapılmıştır. Kaydın yapılacağı cephede, zeminde bulunan podyum blokları ve kapak teknenin tüm yüzeyini kapsayan tek bir RTI kaydına izin vermemiştir. Bu sebeple lahdin ön yüzü; sol kabartma, yazıt ve sağ kabartma olmak üzere üç bölüm halinde kaydedilmiştir (Fig 2).

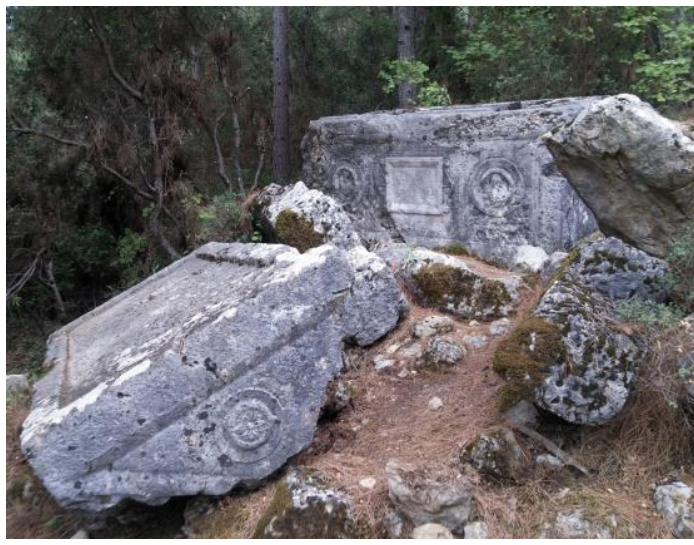

Fig. 1. Beşiktaş mevkii lahit mezarın; tekne, kapak ve podyum bloklarının genel görünümü

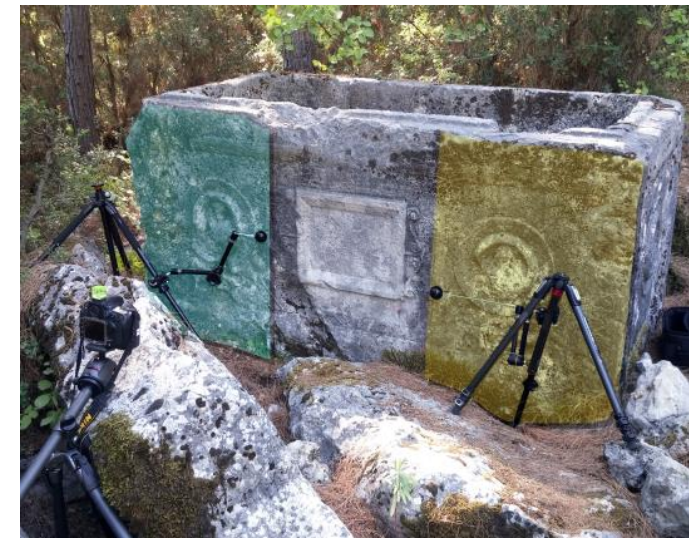

Fig. 2. Beşiktaş mevkii lahit teknesinin tabula kısmının H-RTI kurulumu ve kayıt için ayrılmış diğer alanlar

Lahdin yüzeyine ait elde edilen üç ayrı RTI görüntüsü üzerinde, bölünmüş bir analiz yapmak çalışmanın verimliliğini düşürebilmektedir. Zira farklı RTI verilerini birleştirmek ve tek bir dosya haline getirmek henüz mümkün değildir. Bu kısıtlamayı aşmak için 2017 yılında söz konu lahit üzerinde alternatif bir çalışma yürütülmüştür. Lahdin tüm yüzeyi fotogrametri metoduyla (SfM) kaydedilmiş ve üç boyutlu sayısal modeli elde edilmiştir ${ }^{16}$. Elde edilen fotogrametrik model üzerinde RTI

ekmektedir. Bu mesafenin ölçümünde yüzeyin diyagonal uzunluğunun 2-4 katı baz alınmaktadır.

Sayısal 3D modelin oluşturulması aşamasında lahit yüzeyinin 92 adet fotoğrafı kaydedilmiştir. Kaydedilen bu görüntü dizisi Agisoft Photoscan Pro yazılımı üzerinde sentezlenerek Structure from Motion yöntemiyle yüzeyin hassas üç boyutlu fotogrametrik modeli oluşturulmuştur. Kayıt sırasında lahdin sol alt köşesinde bulunan bloklar, bu kısımdan görüntü alınmasına engel olmuştur. Ancak mevcut korunma durumuyla bu alandan görüntü 
kaydının gerektirdiği ışık dağıımı yapay olarak yazılım üzerinde uygulanarak yüzeyin Virtual-RTı (V$R T I)$ modeli oluşturulmuştur. Bu yöntem ile ayrı parçalar üzerinden bölünmüş bir RTI analizi gerçekleştirmek yerine, lahdin tüm yüzey verilerini tek görüntüde barındıran, gerek 3D model gerekse yapay RTI görüntüsü üzerinden bütüncül bir çalışmanın yürütülebileceği veriler üretilmiştir (Fig. 3-4).

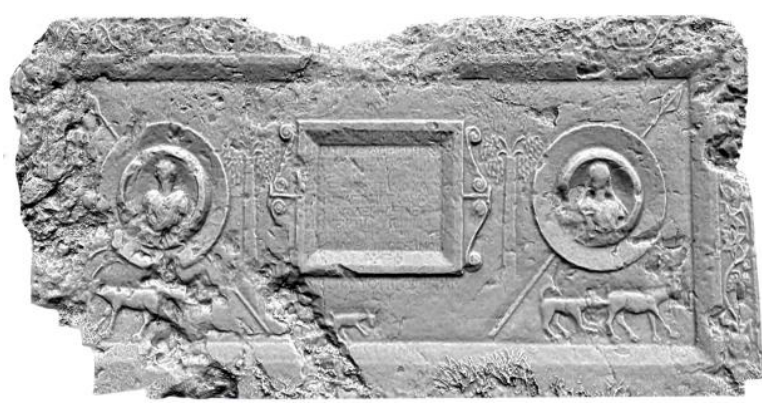

Fig. 3. Beşiktaş lahit teknesinin sayısal 3D yüzey modeli

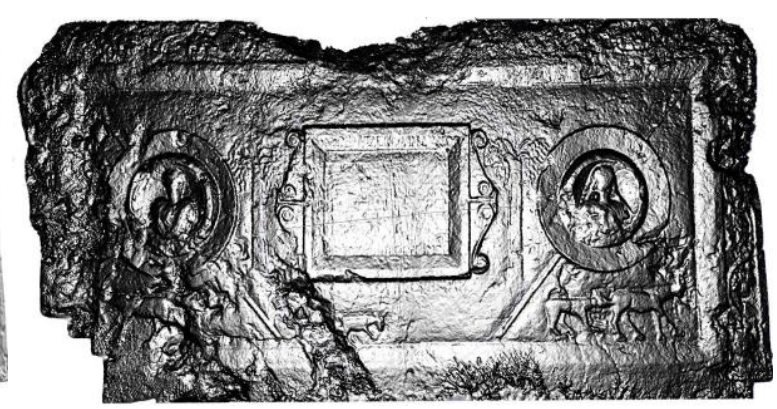

Fig. 4. Beşiktaş lahit teknesinin V-RTI görüntüsü, specular enhacement görünümü

2016 yılında Kırtepe'de tespit edilen, yüzeyinde fungal etkilerin sebep olduğu beyaz lekelenmeler ve özellikle yazıt üzerinde aşınmaların görüldüğü bir lahit mezar tespit edilmiştir (Fig. 5). Yerinde okuması yapılan ve estampaj kopyaları üzerinden çözümlenmeye çalışılan yazıtın içeriği, tahribat nedeniyle tam olarak anlaşılamamış ve 2017 yılı teritoryum çalışmalarında söz konusu lahit RTı metodu ile tekrar belgelenmiştir. Lahit teknesi oldukça büyük boyutlara sahip olmasına rağmen (2.25 m boy - 1.53 m yük.) bulunduğu alanda RTI kurulumuna ve ışık dağıımına engel olabilecek bir unsur bulunmadığından tüm yüzey detayları tek bir RTı kaydı ile tamamlanabilmiştir. Kırtepe'deki lahit teknesi arazi koşullarında kaydedilen en büyük RTI kayıtlarından biri olarak başarılı bir şekilde belgelenmiştir.

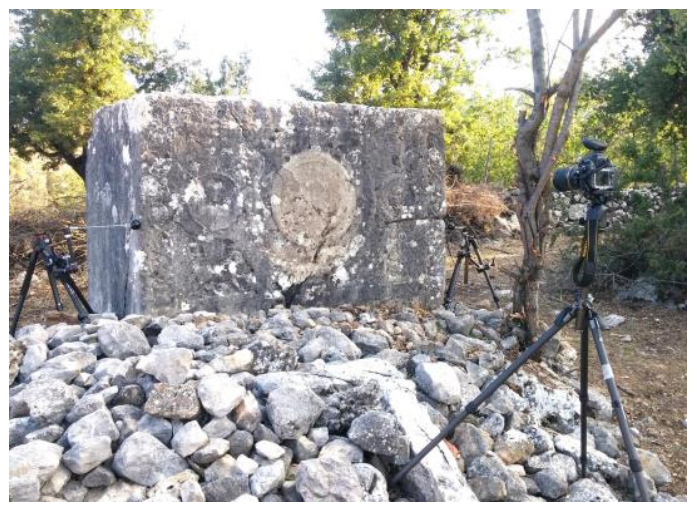

Fig. 5. Kırtepe mevkii 1 no'lu podyumlu lahit mezar genel görünümü ve H-RTI kurulumu

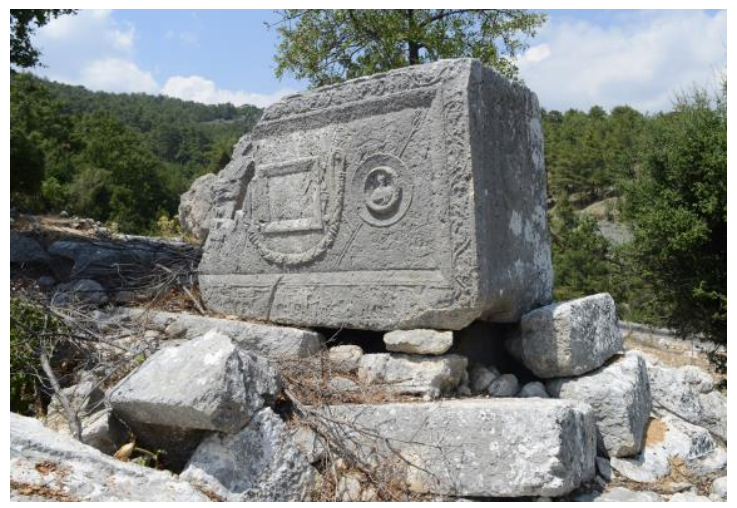

Fig. 6. Kırtepe mevkii 2 no'lu podyumlu lahit mezar genel görünümü

Kırtepe mevkiinde yer alan bir diğer lahit mezar ise yol kenarında bulunmaktadır ve alanın genel görünümünde ciddi bir tahribat izlenmektedir (Fig. 6). Üzerinde birçok bezemenin yer aldığı teknenin ön yüzü de bu tahribattan fazlasıyla etkilenmiştir. Mezarın yanından geçen modern yol bu tahribatı artırmış olmalıdır. Bu lahit teknesi de H-RTI kaydına tabi tutulmuş ve herhangi bir kısıtlama olmadan arazi koşulları altında tüm yüzeyi belgelenmiştir.

alınsa dahi yüzey detaylarına dair veri sunamayacak kadar aşındığı gözlemlenmiştir. 
Son olarak Gedelma'nın yaklaşık 5 km kadar güney batısına düşen Yaylakuzdere Mevkii'nde yalnızca bir bölümüne ulaştığımız semerdamlı kapak üzerinde RTı kaydı yapılmıştır. Kapağın alınlık kısmına kazınmış 12 satırlık yazıt, yüzeydeki bozulmalar nedeniyle yer yer izlenebilmektedir. Alandaki oldukça yoğun bitki örtüsü gerek RTI kurulumunu gerekse kayıt sürecini zorlaştırmıştır.

\section{Lahitlerin RTI Analizleri}

Çalışmamıza dahil edilen lahitlerin RTI analizleri aşamasında, yüzeye farklı noktalardan (sanal) yanal ışık uygulanmasına rağmen halen belirsiz görünen yıpranmış veriler metodun sunduğu çeşitli görüntüleme filtreleri kullanılarak detayların ortaya çıkarılmasına katkı sağlamıştır.

Bu filtrelerden Diffuse gain (yaygın kazanç) dokusal morfoloji algısını artırarak aşınan rölyef ve insizyonların tanımlanmasına katkı sağlamışıı ${ }^{17}$. Örneğin; Beşiktaş'ta bulunan tekne üzerinde hurma ağacının hevenkleri, yaban keçisinin boynuz detayları (Fig. 9); Kırtepe II no'lu lahitteki tek girlandın detayları ve ana sahneyi çevreleyen üst frizdeki sarmal dalların birleşim noktasındaki amphora, diffuse gain ile net olarak tanımlanabilmiştir.

Specular enhancement (yansı katkı) analiz aşamasına katkı sağlayan diğer bir görüntüleme filtresidir. Nesne yüzeyine yapay yansıtma değerleri uygulanan bu filtrede, renk değerleri ortadan kaldırılmakta ve sadece yüzey topografyasına ait görüntü verileri açığa çıkmaktadır ${ }^{18}$. Çalışmada incelediğimiz lahitlerde, fungal etkilerden kaynaklı yüzeyde görülen lekelenmeler direkt veya fotoğraflama yoluyla yapılan analiz sırasında görsel algıyı zayıflatmaktadır. Söz konusu filtre ile lekelenmeler ortadan kaldırarak sadece yüzeye ait topografik verileri üzerinden gerek yazıt gerekse plastik kabartmalara dair detaylı bir analiz çalışması yürütülmüştür. Beşiktaş'taki lahit teknesi üzerinde bulunan mezar yazııının özellikle tabula ansata'nın üst çerçevesine kazınmış olan mezar sahibinin ve babasının isimleri bu filtrede oldukça net bir şekilde belgelenmiştir.

Işığın yüzeyde yansıma yönünü betimleyen normals visualization çalışmada incelediğimiz lahitlerin analizine katkı sunan diğer bir filtredir ${ }^{19}$. Özellikle Kırtepe I no'lu lahitte kadın büstünün boynundaki küçük boncuklardan oluşan kolyenin ve altında bulunan çocuk figürünün elinde tutmuş olduğu objenin papirüs olabileceği fikrini ortaya çıkarmıştır (Fig. 15-16). Aynı lahitte tabulanın iki yanında yer alan dört yunus balığının detaylı tasviri açığa çıkarılmıştır. Bununla birlikte Kırtepe ॥ no'lu lahit üzerinde son derece ilgi çekici bir figürün tespit edilmesini sağlamıştır. Savaş sahnesi kompozisyonunda yer alan tubicen'in tuba çalarken tasvir edildiği sahne diffuse gain ve yüzey normallerinin dağııımı sayesinde görünür kılınmıştır (Fig. 19).

Diffuse gain'in pikseller arasındaki karşıtlık değerini artırması nedeniyle modele ait yüzey dokusunda renk değişimleri meydana gelebilmektedir. Bu nedenle nesnelerin renk analizinde kullanılması önerilmemektedir. Detaylı bilgi için bk. Cultural Heritage Imaging 2013, 14. Earl et al. 2010, 3; Cultural Heritage Imaging 2013, 14.

19 RTI Viewer'da yüzey normalleri (surface normals) seçeneği ile yüzey detayları RGB renk kanalları aracılığıyla (genellikle mavi-kırmızı tonlarda) vektörlerin düzlemdeki dağılım yönünü gösteren bir görüntü sunmaktadır. Yüzey normalleri seçeneğiyle, kaydı yapılan nesnelerin RTI görüntülerinin kalitesine dair gözlemlerin yanı sıra materyallerin farklı zamanlarda yapılan RTI kayıtları üzerinden tahribat analizi yapılabilmektedir. Ayrıca bk. Zanyi et al. 2007, 22. 


\section{RTI Metodu Işığında Arkeolojik ve Epigrafik Değerlendirmeler}

\section{Yaylakuzdere Mevkii Yazıtlı Semerdam Kapak}

Gedelma'nın yaklaşık 5 km kadar güney batısına düşen Yaylakuzdere Mevkii'nde, teraslar şeklinde düzenlenmiş tarım alanlarından çiftlik olabilecek yapı kalıntıları yakınında bulunan, kireçtaşından semerdam çatılı lahit kapağı 0.59 m yüksekliğinde ve 1.18 m genişliğinde olan kapağın dar yüzünde 12 satırlık bir mezar yazıtı tespit edilmiştir. Yazııın özellikle ilk 5 satırı oldukça tahrip olmuş durumdadır. Söz konusu yazıt özellikle specular enhancement filitresinin algılamaya sunduğu katkı ile çözümlenebilmiştir.

Harf Yüksekliği: 0.028-0.030 m. Tarih: MS III. yüzyıl (harf karakterleri dolayısıyla)

2

4

6

8

\section{$10[\pi \rho \alpha] \gamma \mu \alpha \tau \varepsilon \cup \tau \hat{n}$}

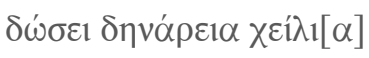

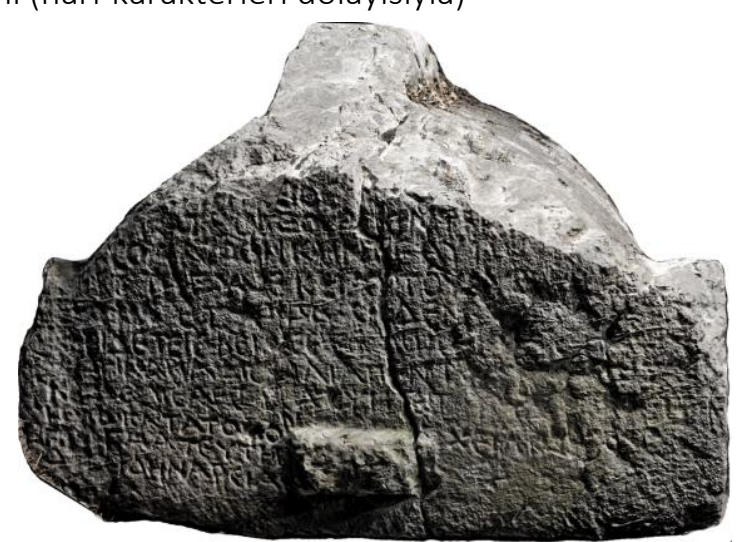

Fig. 7. Yaylakuzdere semerdamlı lahit kapağı ve yazıt

(Falanca oğlu falanca) bu lahdi kendisi, kendisinin karısı ve çocukları için yaptırdı. Başka hiç kimseye izinli değildir. Eğer birisi taciz ederse, (kent ?) kasasına iki bin beşyüz denarii ödeyecek, bunu haber veren kişi ise bu miktarın üçte birini alacak; bu alandan sorumlu olan kişiye ise bin denarii ödeyecek.

Str. 01-02. Yazııın ilk iki satırı kırık olduğu için mezar sahibinin adı öğrenilememektedir.

Str. 3-5. Mezarda yer alan kişiler olarak belirlenmiş olan eş ve çocukların adı verilmemiştir.

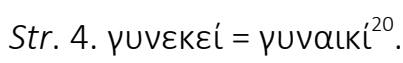

Str. 6. $\tau \varepsilon\llcorner\varsigma=\tau \iota \varsigma ; \beta \varepsilon\llcorner[\alpha \dot{\sigma} \tau \tau]=\beta[[\alpha \dot{\sigma}\rceil \varepsilon]$. Mezar cezasının ödeneceği kurum okunamamakla birlikte,

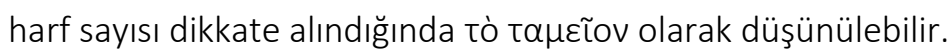

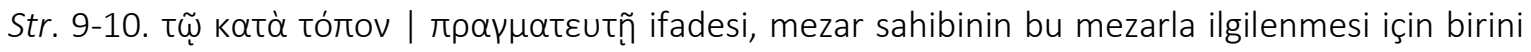
yetkili kıldığını göstermektedir. Bu kişi muhtemelen mezar sahibinin kölesidir. Pragmateutes için bk. Robert 1937, 241 vd.; 1955, 83 dn. 3; Robert 1978, 429, dn. 13. Mezara karşı suç işleyenin ceza ödeyeceği bir merci olarak bir tek burada belgelenmiştir. Lykia Bölgesi'ndeki diğer örnekler için bk. TAM II 59, 603, 1020; SEG XXVIII 1242.

\section{Beşiktaş Mevkii Podyumlu Lahit Mezar}

Tahtalı Dağ’ın kuzey etekleri üzerinde, Beşiktaş mevkiinde yangın yolunun doğusunda bulunan lahit

20 aı çift seslisinin $\varepsilon$ tek seslisine dönüşmesi için bk. Bartoněk 1966; 45; Gignac 1976, 192 vd.; $\varepsilon$ ı çift seslisinin ı tek seslisine yerine kullanılması için bk. Gignac 1976, 189 vd. 
mezar; podyum, tekne ve yerinden kay(dırı)mış kapak olmak üzere üç parçadan oluşmaktadır. Podyum bloklarının bir kısmı tekne ile kapak arasında dağınık olarak bulunmaktadır. Tekne in-situ kalabilen birkaç podyum taşı üzerinde doğu-batı doğrultusunda yer alır ve $1.13 \mathrm{~m}$ en, $2.30 \mathrm{~m}$ boy ve 1.27 m yükseklik ölçülerindedir. Lahit kapağı kırma çatı formunda, 1.25 m en, 2.45 m boy, ve $0.73 \mathrm{~m}$ yükseklik ölçülerindedir. Kapak, mezarın hemen önünde yerde ters durur vaziyettedir. Tekne ve kapak kireçtaşı malzemeden üretildiği için yüzey dokusunda bozulmalar meydana gelmiş yer yer küçük kırıklar ve çatlaklar oluşmuştur ancak genel görüntü itibariyle tüme yakın korunmuşlardır.

Teknenin bir uzun yüzü ve iki dar yüzü bezenmiş, arka yüz işlenmeden kabaca tıraşlanarak bırakılmıştır. Bezemeli üç yüz, kenarları boyunca, dışta geniş bir silme ve içe eğimli daha dar bir silmeden oluşan iki kademeli bir çerçeve içine alınmıştır. Ön yüz çeşitli figürlerle oluşturulmuş yoğun bir sahne sunmaktadır. Bu sahne, yanlardan ve üstten, üzüm salkımı ve asma yaprağı taşıyan sarmal bir dal ile çevrilidir. Sağ alt köşede gövdesi amphora formuna benzer, kulpları ve ağız kısmı tahrip olduğu için tanımlanayan bir kap içinden çıkan tek asma dalı kıvrılarak yükselir ve üst silmeye bağlanır. Bu alanlarda yer yer izlenebilen motif teknenin sol tarafındaki tahribat nedeniyle bu noktadan itibaren takip edilemez ${ }^{21}$. Teknenin ön yüzünde merkezde dikdörtgen formda yazıtlı tabula ansata yer alır. Tabulanın etrafı zeminden yükseltilerek oluşturulmuş iki silmeli bir çerçeve ile sınırlanmıştır. İç bükey silme üzerine yazıtın ilk satırının kazındığı görülür. Tabulanın merkez hizasında, sağ ve sol yanından çıkan " $\mathrm{T}$ " şeklindeki dayanaklarda birleşen ucu spiralli ikişer ansata yerleştirilmiştir. Tabula ansatanın iki yanında birer ağaç tasviri ve onlarında yanında kalkan içinde insan büstleri yer almaktadır (Fig. 8).

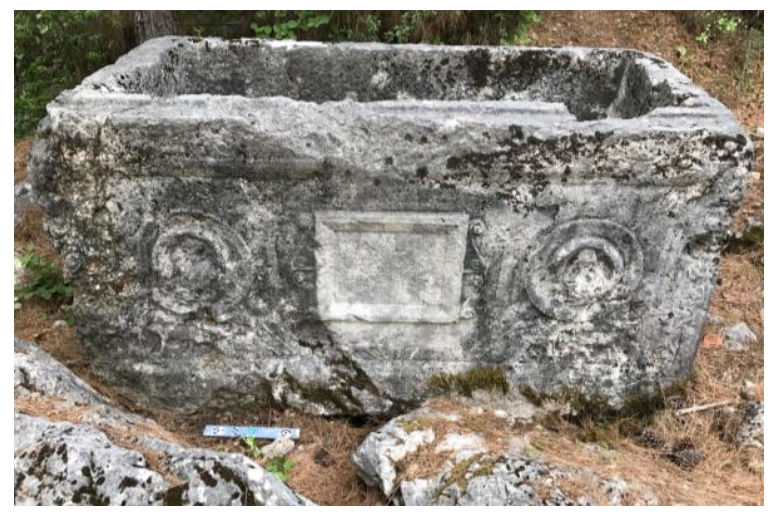

Fig. 8. Beşiktaş, podyumlu lahit ön yüz görünümü

Tabula ansata ile kalkanlar arasında yükselen ağaçlar hurma ağacıdır. Ağaçların ikisi de doğal görünümlerine oldukça yakın tasvir edilmiştir. Yüksek kalın bir ağaç gövdesi, gövdenin tepesinden çıkarak farklı yönlere doğru açılan dört adet dal ve dalların ucundan sarkan hurma hevenkleri detaylı bir hurma ağacı tasviri ortaya koymaktadır. Buradaki ağaç tasvirinde hurmanın tercih edilmiş olması yapraklarını dört mevsim dökmeyen bir ağaç türü olması nedeniyle ruhun ölümsüzlüğünü temsil etmesiyle ilişkilendirilebilir. Ağaç tasvirleri eskiçağdan itibaren Sümer Urartu, Asur, Frig gibi çeşitli kültürlerde kutsal anlamlar içeren bir örge olarak birçok sahne içinde tasvir edilmiştir ${ }^{22}$. Bu betimlemelerde sıklıkla karşılaşılan kompozisyon, ortada bazen gerçek bir anlatım

21 Roma İmparatorluk Dönemi lahitlerinde Dionysos anlatımlı lahit grupları içinde üzüm asmaları ya da girlandlar üzerine takılmış üzüm salkımları kullanılmaktaydı. Söz konusu bezeğin lahitler üzerinde kullanımı için bk. Koch 2001, 150, 165, 204, 211, 249; Asma dalları ikonografisi ve Olympos'ta girlandlı bir lahit kapağında kullanılan sarmaşık ve üzüm salkımı Dionysios ile ilişkili olabileceği yönünde değerlendirilmiştir, bk. Özer 2013, 491-492, Fig. 14; Ayrıca Antalya Müzesi'nde yer alan ön yüzü tamamen sarmaşık dallarla bezeli lahit teknesi tarihlemesi tam yapılmamış bir eser olmakla birlikte Roma İmparatorluk Dönemi lahitleri içinde erken dönem örneklerinden biri olarak kabul edilirse, örneği olmayan bezeme sahnesi ile frizli lahitlerin öncüsü olarak değerlendirilmektedir. Ayrıntılı bilgi için bk. Koch 2001, 216.

22 Urartu kültüründeki hayat ağacı için bk. Belli 1982, 237-247; Çevik 1999, 336-367; Olympos nekropolisinde bulunan kireçtaşından bir lahit teknesinin yanlardaki plasterlerlerinin üzerinde altta birer kantharos biçimli kap ve bunlardan çıkan sarmaşık motifleri bulunmaktadır. Bu motifler İdil tarafından Ön Asya'da Sümerlerden başlayarak gelişen "Hayat Ağacı" kavramının Roma İmparatorluk Dönemi’ndeki betimleniş şekli olarak yorumlanır, 
içinde bazen stilize edilmiş bir ağaç tasviri ve iki yanında karşılıklı duran hayvanlardan oluşmaktadır $^{23}$. Buradaki ağaç tasvirleri, kutsal ağaç ikonografisinden ziyade yaşam döngüsü içinde kendini devamlı yenileyen, doğa ile uyum içinde ve doğanın vazgeçilmez bir parçası olarak var olan ağacın, hem toprağın içinde hem dışında devam eden yaşamı sembolize etmesi şeklinde değerlendirilmektedir (Fig. 9).
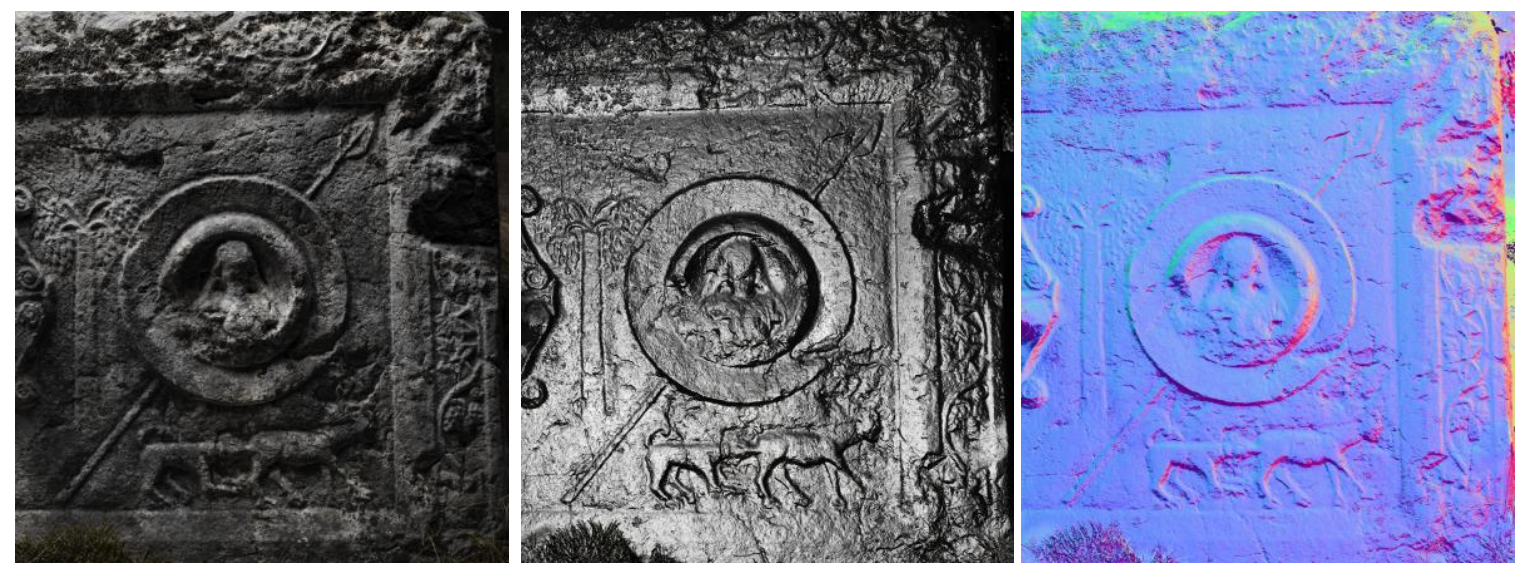

Fig. 9. Beşiktaş mevkii lahit teknesinin sağ tarafında yer alan hurma ağacı, kalkan içinde kadın büstü ve altta av köpeğinin geyiği yakalama anı RTI görünümleri

Tabulanın sağında ve solunda kabartma halinde kalkan ve içinden geçen mızrak tasiviri yer alır. Kalkanlar iki kademeli yuvarlak çerçevelerden oluşur. Dış çerçeve çizgisi yüzeyden kabartılmış daha sonra ortaya doğru içe eğimlenerek gelmiştir. İç çerçeve de, merkeze doğru gelindikçe hafifçe çukurlaşmış ve bu alana tasvir edilmek istenen figür yerleştirilmiştir. Mezarda, teknenin ön yüzünde iki adet, dar yüzlerde birer adet ve kapağın iki alınlığında birer adet olmak üzere toplam altı adet kalkan yer almaktadır. Bu kalkanların tümü tanımı yapılan yuvarlak kalkan tasvirleri ile aynı olup yalnızca ortalarında betimlenen figürler değişmektedir. Tabula ansatanın sağındaki kalkan içine kadın büstü yerleştirilmiştir. Figürün yüzü oldukça tahrip olmuştur ancak başından omuzlarına dökülen örtü belirgindir (Fig. 9).

Kadın büstünün altında, bir geyik ve av köpeği tasvir edilmiştir. Geyiğin vücudu yandan, yüzü ise profilden verilmiş, boynuzları ve ayak toynakları belirtilmiştir. Arkasında duran av köpeği geyiği kuyruğundan yakalamak üzereyken ağzı açık olarak betimlenmiştir. Köpeğin kulakları aşağı doğru sarkık, kuyruğu yukarı doğru kıvrılmış ve ayaklarındaki pençe detaylarına kadar işlenmiştir (Fig. 10). Tabulanın solunda kalkan içinde yüzü büyük oranda tahrip olmuş bir erkek büstü yer alır ve altında bir dağ keçisi bulunmaktadır. Keçinin uzun boynuzları arkaya doğru kıvrıımış olup kalkanın dış kontur çizgisine değer. Sağ taraftaki sahne ile benzer şekilde keçiyi yakalamış bir hayvan figürü beklense de, lahdin bu bölümü oldukça tahrip olduğu için keçinin arkasında başka bir hayvan olup olmadığı anlaşılamamaktadır (Fig. 11). Tabulanın alt sol tarafında tek olarak betimlenmiş bir hayvan figürü daha yer almaktadır. Bu figür teknenin ön yüzünde tasvir edilen diğer hayvanlara oranla küçüktür. Ön ayakları gergin ileri doğru atıırken görülür. Yüzü profilden verilmiş, kulakları havada betimlenen bu figür keçi yavrusuna benzemektedir.

İdil 1998, 48-49, Lev. 38, 2-3; Özer 2013, 486, Fig. 6.

23 Urartu tasvirleri için bk. Belli 1982, s. 247 Fig. 1-2, Frig tasvirleri için bk. Köroğlu 1996, Lev. II,III,VII-a, IX-b, XIV, $\mathrm{XV}, \mathrm{XV}$. 
Yavru keçinin sahnedeki duruşu, karşısında bir hayvanın daha yerleştirilmiş olabileceğini düşündürmektedir, zira bu durumda tabulanın sağ alt köşesi de doldurulmuş olacaktır. Ancak mezara uygulanan RTI ve fotogrametri yöntemleri burada herhangi bir işlemin yapılmadığını ortaya koymuştur. Teknenin doğu dar yüzünde kalkan ve mızrak kabartması yer alır, kalkanın ortasına çiçek motifi yerleştirilmiştir bu taraf aynı zamanda gömünün başının yerleştirildiği yastık bölümünün olduğu yöndür. Batı dar yüzde yine bir kalkan mızrak kabartması yer alır. Buradaki kalkan bir erkek büstü taşımaktadır. Yüzü tamamen tahrip olan erkek figürün, sol omuzu üzerinden gövdesine diagonal inen giysisi görülür.

Lahit kapağının bir uzun yüzü üzerinde, gövdesi profilden yüzü ise cepheden verilmiş ayakta duran bir aslanın sağ kolu ile boğayı yakaladığı sahne kabartma olarak işlenmiştir (Fig. 12). Aslan ayakta durmaktadır ve yüzü yukarı dönüktür. Yüz hatları yuvarlak, elmacık kemikleri belirgin, yanakları dolgun ve etlidir. Göz çukuru iri yuvarlak hatlarla belli edilmiş, kaş çizgisi işlenmiştir. Ağzı açıktır ve alttan iki sivri diş görünmektedir. Yeleleri yüzün etrafını çevreleyen yüzeysel yiv

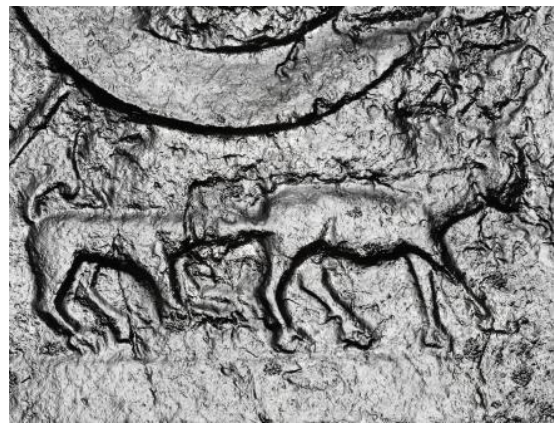

Fig. 10. Av köpeği ve geyik detay (RTI)

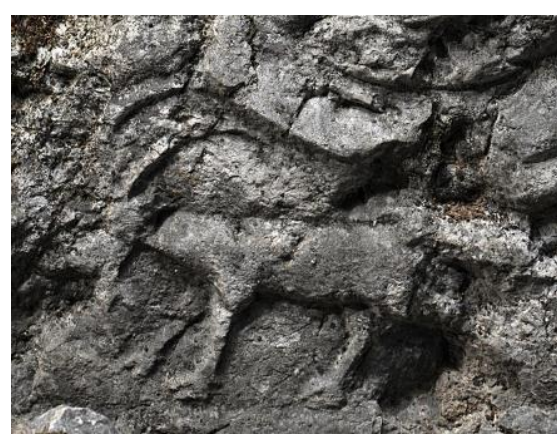

Fig. 11. Dağ keçisi detay (RTI) izleriyle belli edilmiştir. Gövdesi kabaca tıraşlanmış, ön ve arka ayaklarda pençe detayları verilmiştir. Aslanın sağ pençesi ile ağzından yakalamış olduğu boğa, profilden ve yalnızca baş olarak görülür ${ }^{24}$. Avlanan hayvanın ağız kısmı aslanın pençesi altında kalmış, boynuz kulak ve göz detayları işlenmiştir. Kapağın iki alınlığında ortasında birer çiçek tasviri yerleştirilmiş kalkan yer alır. Bu çiçek tasvirleri birbirinden farklı yapraklara sahiptir. Batı dar yüzde yer alan çiçek, uçlara doğru sivrilerek gelen altı tam yaprak ve onların arasındaki boşluklara yerleştirilen yine uçları sivrilerek gelen altı yarım yapraktan oluşur. Böylelikle motife katmerli bir görünüm verilmiştir. Doğu dar yüzde yer alan çiçek ise dört yapraktan oluşur ve daha sade bir görümdedir. Kapaktaki bir diğer bezeme örgesi de yüzeyden

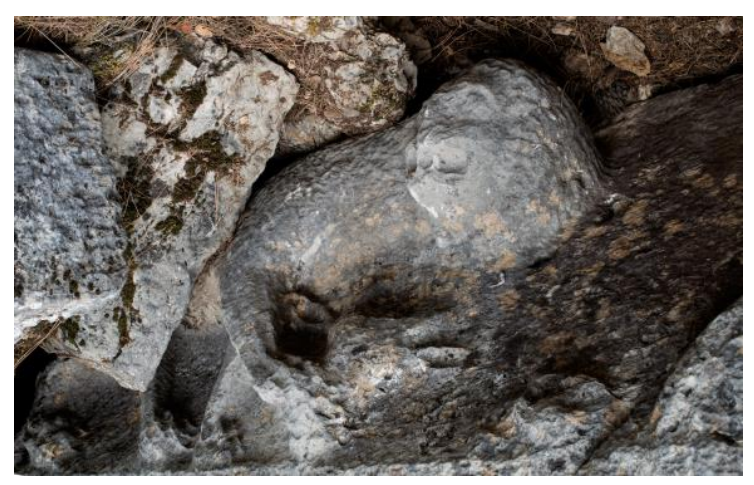

Fig. 12. Aslanlı lahit kapağı detay

24 Doğu Lykia kentlerinden Idebessos'ta ele geçen bir lahit kapağının uzun yüzü üzerine de bir aslanın boğayı başından yakalamış olduğu sahne kabartma olarak işlenmiştir (bk. Kızgut et al. 2009, 145 vd. Fig. 30); Kuzey Lykia kentlerinden Balboura'da da benzer kapaklar mevcuttur (bk. Money, 1990, 29 vd. Levha 4, (a) N14, (b) C10, (c) M1); Kilikia, Lykaonia ve Isauria'da ise, çatı biçimi kapaklar üzerinde, yatar konumdaki aslanların tam plastik yöntemiyle betimlendiği görülür (bk. Koch 2001, 212, Fig. 10); Isauria bölgesindeki Adrassos'taki örnekler içi bk. Alföldi-Rosenbaum, 1980, 47-52; Isauria bölgesi kaya mezarlarındaki aslan ve yanında baş olarak işlenmiş boğa tasviri için bk. Doğanay 2009, 440-441, Lev. 26-27. Olba Bölgesi Korykos’taki aslanlı kapak tasviri için bk. Karaüzüm 2005, Lev. 63, fig. 99; Lahit tekneleri üzerinde tasvir edilen boğa aslan mücadelesi hakkında bilgi için bk. Koch 2001, 153; Ksanthos'ta da Aslanlı Mezar olarak adlandırılan lahit mezarın kapağının güney yüzünde yatar pozisyonda başı cepheden verilmiş bir aslanın, sadece başı ve boynu görünen bir ceylanı boğazından tuttuğu sahne yer alır. Kabartmaların detaylı anlatımı, tasvirlerin anlamı ve kökeni üzerine değerlendirmeler için bk. Özüdoğru 2013, 69-86. 
görülebilen akroterlerden birinde yer alan palmet bezeğidir. Üç yapraktan oluşan açık palmet bezeğinin yaprakları köşe akroterini kaplayacak şekilde yerleştirilmiştir.

\section{2a. Hermas ve Ailesinin Mezar Yazıtı}

Lahit teknesinin ön yüzünde yer alan tabula ansata üzerinde -ilk bir ve son dört satııı çerçeve üzerinde ve dışında olmak üzere- 14 satılık yazııı bulunmaktadır. Yazıt yüzeyi oldukça tahrip olmuş durumdadır. Gerek yazııı korunum durumu gerekse ışık konumundan dolayı geleneksel yöntemlerle okunamamış olan söz konusu yazıt, RTI metodu kullanılarak çözümlenmiştir.

Harf Yüksekliği: 0.02-0.04 m.

Tarih: MS III yüzyıl (mezar sahibinin taşıdığı Aurelius gens ismi ve harf karakteri (Ф) dolayısıyla 212 sonrası)

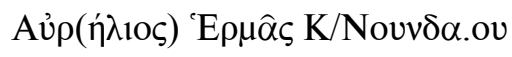

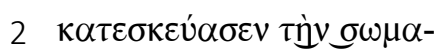

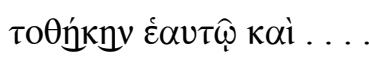

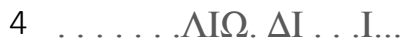

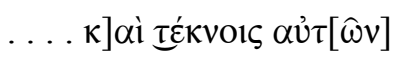

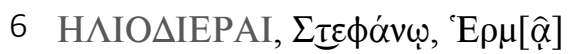

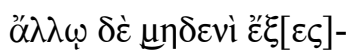

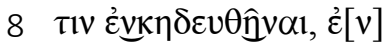

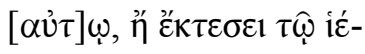

$10 \rho \hat{\omega} \tau \alpha \mu \varepsilon i \hat{\omega} \pi \rho \sigma \sigma \tau \varepsilon \dot{\mu} \mu \mathrm{ov}$

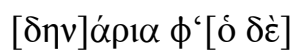

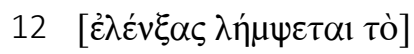
$\tau \rho i ́ \tau o v ~ \tau o \widehat{v} \pi \rho о \gamma \varepsilon \gamma \rho \alpha \mu-$

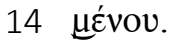

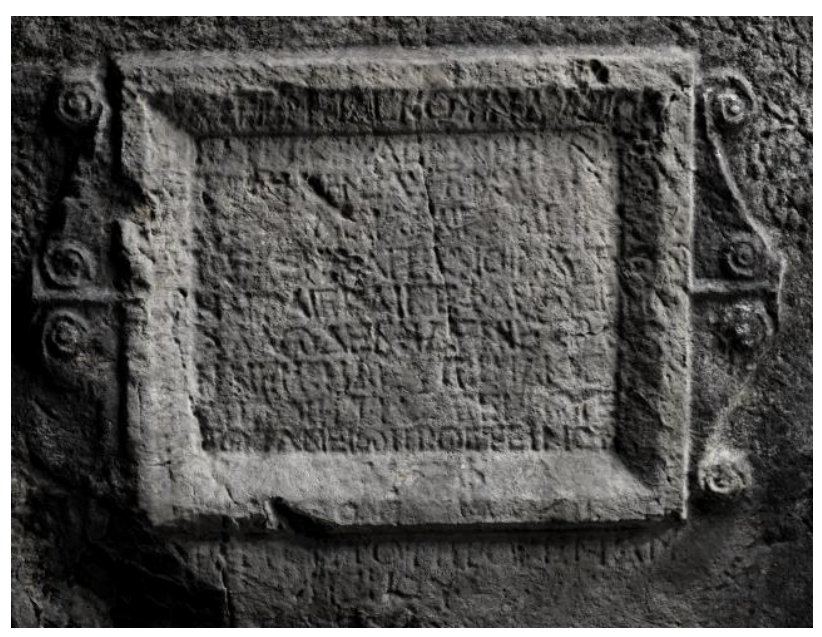

Fig. 13. Beşiktaş mevkii, Hermas ve Ailesinin mezar yazıtı

(RTI)

Koundalos(?) oğlu Aurelius Hermas bu lahdi kendisi ve [karısı falanca kızı falanca] ve çocukları Heliodiera/Heliodora, Stephanos (ve) Hermas için inşa ettirdi. Başka hiç kimseye burada gömülmek izinli değildir, aksi taktirde kutsal kasaya belirlenmiş olan ceza tutarı değerindeki beş yüz denarii ödeyecek, bunu haber veren kişi ise yukarıda yazılan tutarın üçte birini alacak.

Str. 1. Mezar sahibi Hermas'ın babasını adlandıran ismin ilk harfi net olarak görülememekle birlikte kappa ( $\mathrm{k}$ ) ya da ny $(v)$ harflerine ait olabilecek izler taşımaktadır. Sonrasında gelen dört harf net olarak tespit edilebilmekte; fakat sondan üçüncü harf okunamamaktadır. Dolayısıyla burada, genetivus casus'ta verilmiş, sonu -oç ile biten mascilinum bir isim söz konusudur. Eğer ilk harf ny ise, Nouv $\delta \alpha$ - ile başlayan isimler taranabilir. Fakat şimdiye kadar Nouv- ile başlayan isimler bilinse de (Zgusta 1964, 365; LGPN V/A 340; VB 322), bu haliyle belgelenen olmamıştır. Illk harfin kappa olması durumunda ise intimaller artmaktadır. Telmessos kentinden ele geçen bir Kakasbos adağında, genetivus casus'ta Kouv $\delta \alpha \lambda$ ı tespit edilmiştir (Petersen - v. Luschan 1889, 3. Nr. 3; TAM II 8; Robert 1946, 46 vd., nr. 3; krş. Zgusta 1964, $254 \S 732-3)^{25}$. Aristoteles'in Oikonomia adlı eserinde Karia kralı Mausolos'un komutanı olarak geçen Kondalos (Arist. Oecon. 1348a 18:

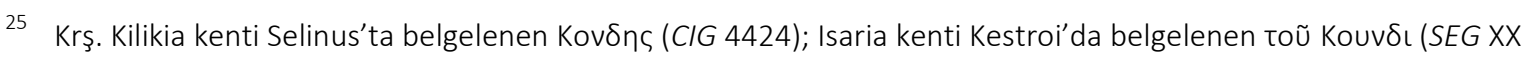

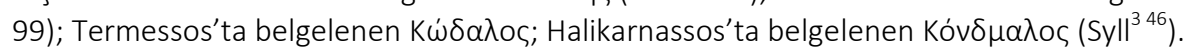




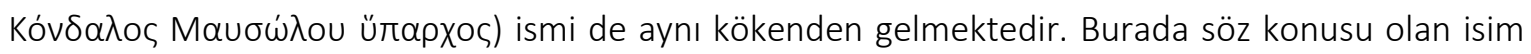
de, yukarıda ele alınan örneklere dayandırılarak Kouv $\delta \alpha[\lambda]$ os olarak önerilebilir.

Str. 4-5. Bu satırlar arasında, Hermas'ın karısının dativus casus'ta ve karısının babasının genetivus casus'ta beklenen isimleri yer almalıdır.

Str. 7. Mezar sahibi Hermas'ın üç çocuğu olduğu öğrenilmektedir. Fakat bunlardan sadece ikisinin ismi net olarak okunabilmektedir. Satır başında yer alan ilk isme ait olan harflerden dativus casus'ta $H \lambda \iota$ $\delta\llcorner\varepsilon \rho \underline{\alpha}$ ismi okunmaktadır. Böyle bir isme şimdiye kadar rastlanmamıştır. Esasen burada 'H$\lambda \iota \circ \delta \omega ́ \rho \alpha$ ismi beklenebilir. Bu durumda yazıtı yazan ustanın burada bir hata yaptığı düşünülüp

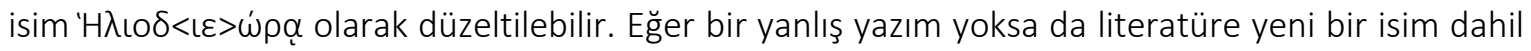
edilmiş olur. Diğer iki oğlunu adlandıran isimler olan Stephanos ve Hermas isimleri de şimdiye kadar Phaselis kenti ve teritoryumunda belgelenmemiş olsalar da Lykia'da karşılaşılan isimlerdendir (krş. Stephanos için LGPN V/B 389; Hermas için LGPN V/B 147).

Str. 10-12. Söz konusu satırlar arasında, yazıtta izin verilenler dışında mezara birini gömenin nereye

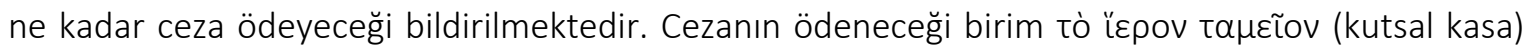
olarak belirtilmektedir. Buradaki kasanın kutsal sıfatı ile verilmiş olmasından dolayı bir tapınak kasasına mı, kent kasasına mı, yoksa Roma İmparatorluğu'na ait kasaya mı (= fiscus) işaret ettiği belli değildir ${ }^{26}$. Fakat her ne kadar kesin bir kanıt olmasa da imparatorluğa ya da imparatora ait kasa söz konusu olduğunda fiscus'u ifade etmesi için genel olarak hierotaton tameion adlandırmasının kullanıldığı kabul edilmektedir ${ }^{27}$. Dolayısıyla burada geçen kasa muhtemelen tapınak ya da kent kasası olmalıdır. Eğer bir tanrıya ait ise, tanrının adının verilmemiş olması dolayısıyla hangi tanrıya ait tapınağın söz konusu olduğu konusunda net bir şey söylenemez ${ }^{28}$. Olympos kentindeki

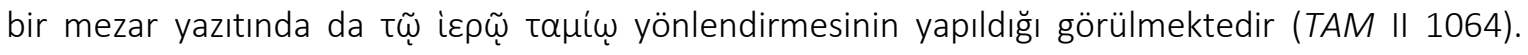
Burada muhtemelen kent kasası kastedilmiş olmalıdır. Bugüne kadar Phaselis kentinden ele geçmiş

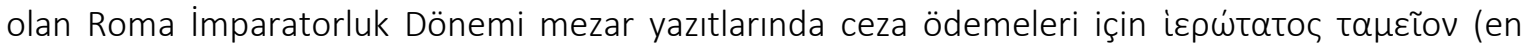

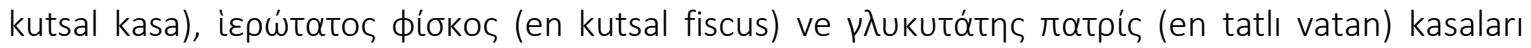
yetkili kılınırken ceza tutarlarının 500-1000 denarii olarak belirlendiği tespit edilir ${ }^{29}$; teritoryumda ise şimdiye kadar sadece tek bir mezar yazıtında ceza emaresi korunmuştur, bu da kent kasasına

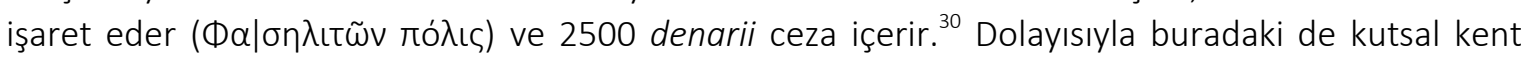
kasası olarak kabul edilebilir.

\section{Kırtepe Mevkii I no'lu Podyumlu Lahit Mezar}

Üçoluk Mahallesi, Kırtepe Mevkii Yusuf Horanlı́nın tarlasında bulunan lahit mezar; in-situ konumda podyum ve tekne ile yerinden kay(dırıl)mış kapak olarak üç parçadan oluşmaktadır. Mezarın ham maddesi kireçtaşıdır. Podyum 0.46 m yüksekliğindedir ve blok taşlarla örülmüştür. Görünebilen kısımlarında bloklar eksiktir, bir uzun yüz ile bir dar yüz ise tamamen moloz dolgunun altındadır. Tekne podyum üzerinde doğu-batı doğrultulu ve $1.23 \mathrm{~m}$ en, $2.25 \mathrm{~m}$ boy ve $1.53 \mathrm{~m}$ yükseklik

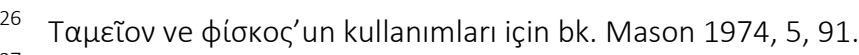

27 Bu konu hakkındaki ilgili yorumlar için bk. Rossi 1975, dn. 156; krş. Avcu 2014, 27-29.

28 Tanrı ismi belirtilmeden verilen diğer tapınak kasaları için bk. TAM II 226; Schweyer 2002, 259 nr. 72; Davies 1895, nr. 8; Avcu 2014, 29 vd.

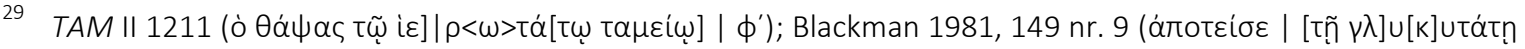

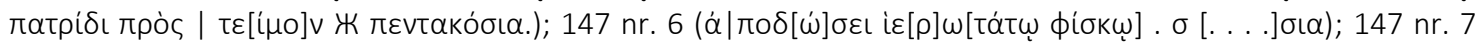

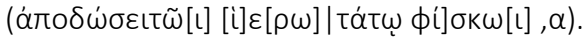

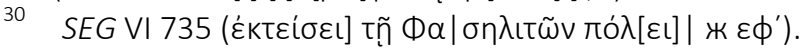


ölçülerindedir. Kapak mezarın hemen önünde ters durur vaziyette ve içi tamamen moloz taşlarla doludur. Kapak ölçüleri 1.30 m en, 2.45 m boy ve 0.57 m yükseklik olarak tespit edilir (Fig. 5).

Üzerinde kabartmaların ve yazııın yer aldığı tekne yüzeyinde, taşın ham maddesinin bozulmalara açık yapısı dolayısıyla doğal ve beşeri unsurların da etkisiyle deformasyon ve taş bünyesinde çatlaklar oluşmuştur, ancak kırık ve eksik parça olmadığı için eser genel görünüm itibariyle tüme yakın oranda korunmuştur.
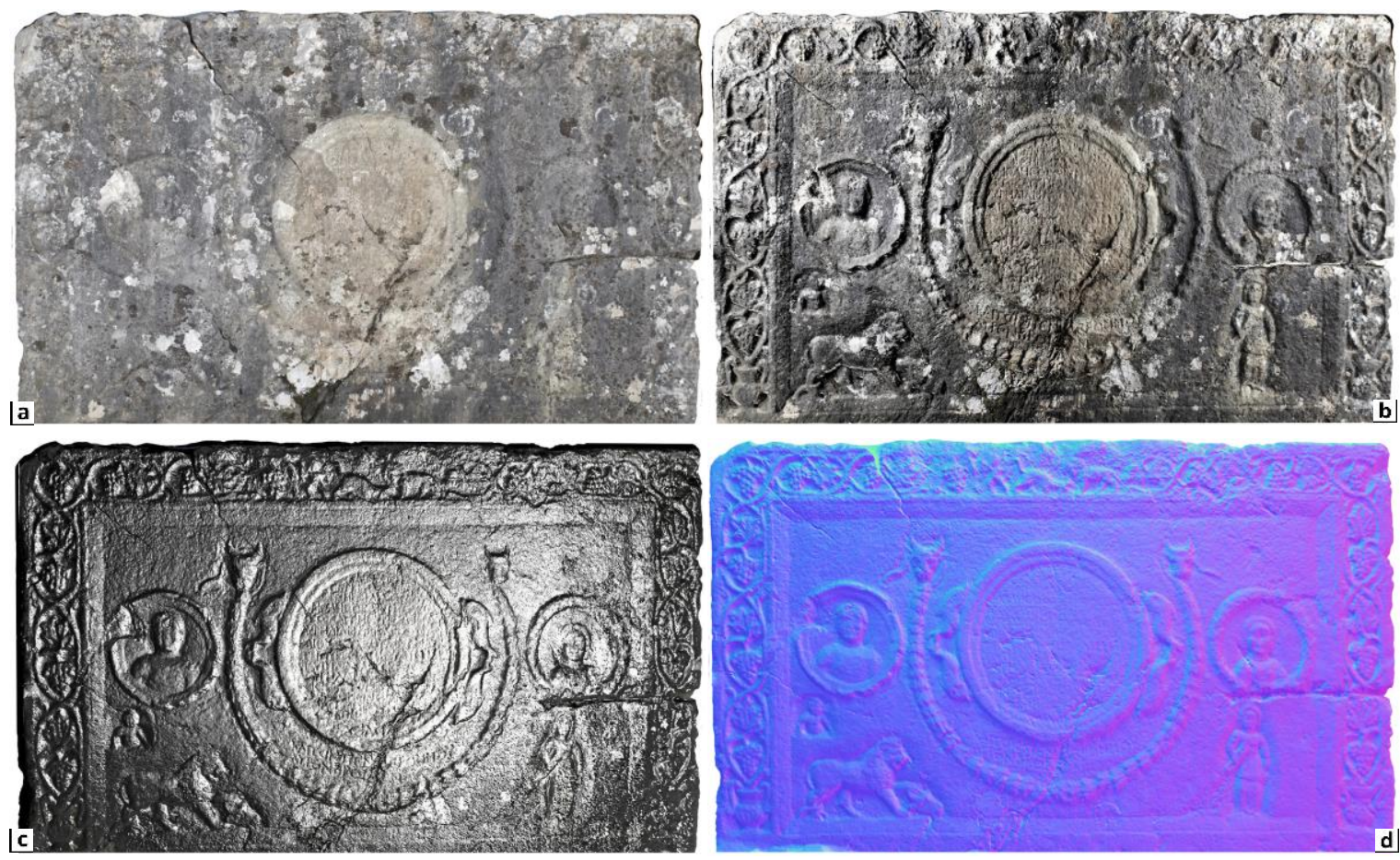

Fig. 14. Kırtepe lahit teknesi RTI analizi görüntüleri: (a) Işığın yüzeye direkt düştüğü açıdan kaydedilen RTI görüntüsü. (b) Derinliği artırarak rölyef detaylarının ortaya çıkarılmasında yanal diffuse gain etkisi görüntüsü. (c) Specular enhacement ile yüzeydeki fungal etkilerden ve renk değerlerinden arındırılmış, sadece yüzey topografyasına ait RTI görüntüsü. (d) Yansıtma özelliklerini temsil eden yüzey normallerinin dağılımı

Teknenin yalnızca ön uzun yüzü işlenmiştir. Çeşitli figürlerle bezenmiş olan bu yüzde sahnenin etrafı yanlardan ve üstten bir friz kuşağı ile çevrilidir. Yanlarda birer volütlü krater içinden çıkarak yükselen üzüm salkımı ve asma dalı taşıyan sarmal motif görülür. Aynı kap içinden çıkan iki dalın yükselirken kıvrılıp birleşmesiyle oluşan yanlardan basık oval alanların her birinin içine bir üzüm salkımı bir asma yaprağı yerleştirilmiştir. Bu sarmal dallar yükselerek teknenin köşelerinden döner ve üst frize bağlanır, tam yazııın üstüne denk gelen noktada asma dalları karşılıkı olarak birer üzüm salkımı ile sonlanarak yerini insan ve hayvan figürlerine bırakmıştır. Böylelikle yanlarda asma dalları ortada insan ve hayvan figürü taşıyan karma bir friz elde edilmiştir. Buradaki figürlerde av ve mücadelenin konu edildiği bir sahne betimlenmiştir. Solda elindeki mızrağı havaya kaldırmış, bacakları açık, sağ bacağını bükerek yaylanmış, saldırı anı için hazır pozisyonda betimlenen bir erkek figürü yer alır. Onun önünde karşılıklı duran iki hayvanın mücadelesi konu edilmiştir. Bir aslan sol ayağı ile karşııındaki hayvanı başından yakalayarak yere doğru eğmiş; bu hareketle yenilen hayvanın ön vücudu yere doğru eğilmiş, sağ bacağını geriye doğru atmış ve kuyruğu havada kurtulmaya çalışırken betimlenmiştir. Aslanın alt ettiği bu hayvan, taşın yüzeyindeki tahribat ve aslanın ayağı ile başını kapatması nedeniyle net olarak tanımlanamıyorsa da, vücut hatlarına bakarak leopar benzeri yırtıcı bir tür olduğu söylenebilir. 
Tekne üzerindeki ana sahnenin merkezinde yazıt taşıyıcısı olarak yuvarlak bir tabula yer alır. Tabulanın iki yanında ansata olarak yunuslar tasvir edilmiştir ${ }^{31}$. Sağda ve solda yer alan ikişer adet yunus balığı kuyrukları birbirine değecek şekilde yerleştirilmiştir. Yunusların ağız, göz ve kuyruk detayları ile vücut hatlarındaki kıvrımlar detaylı bir balık tasviri ortaya koymaktadır. Tabulayı tek girland çevrelemektedir. Yalnızca yapraklarla (defne yaprağı) oluşturulan girland ince bir görünümdedir. Girland tabulayı çevreledikten sonra taenialarla bukephalionlara bağlanır. Bukephalionlar boynuz, göz ve dudak hatları belli edilmiş boğa başları olarak işlenmişlerdir. Boğa başlarının ikisinde de boynuzun bir kenarından taenia ucu dalgalanmaktadır. Tabula ansatanın iki yanında yuvarlak birer çerçeve içinde mezar sahiplerinin betimlemeleri yer almaktadır. Bu insan figürleri göğüs alt hizasına kadar işlenmişlerdir. Sağdaki çerçevenin dış hattı girland için kullanılan yaprakla benzer bitki yaprağıyla bezenmiş bir çelenktir ${ }^{32}$ ve içinde kadın büstü yer almaktadır. Figürün etli yüzü, göz çevresi, dolgun yanak, çene ve boyun hatlarının yanı sıra boynuna taktığı küçük boncuklardan oluşan kolyesi RTI metodu sayesinde görülür hale gelmiştir (Fig. 15). Kadının saçları, yüzü çevreleyen yuvarlak bir hatla boyun hizasına kadar uzanır. Onun hemen altında duran bir kız çocuğu yer almaktadır. Figür diz üstünde sonlanan ya da kıvrım yapan bir elbise giymekte ve sağ elinde gövdesine çapraz olarak yasladığı bir obje tutmaktadır. Esere uygulanan RTI yöntemiyle bu objenin, iki silindirik parçadan oluşan formu ve birleşim noktasında derinlik çizgisinin belirdiği görülmüştür. Bu yansımalar ve figürün okul çağında olabilecek bir çocuğu betimlemiş olması nedeniyle objenin sarılmış bir papirüs olabileceği üzerinde durulmaktadır. Kız çocuğunun yüz hatları ve saç işlenişi üstte betimlenen kadın portresi ile yakın benzerlik içindedir (Fig. 16). Tabulanın solunda bu kez bezeme içermeyen bir çerçeve içinde erkek figürü yer alır. Erkek figürünün de yuvarlak yüz hatları, dolgun yanak, çene ve belirgin elmacık kemiklerine sahip olduğu görülmektedir. Erkek figürün sol alt köşesinde tam yuvarlak olmayan hafifçe derinleştirilmiş bir hat içinde yaklaşık bel hizasına kadar işlenmiş bir erkek çocuğu

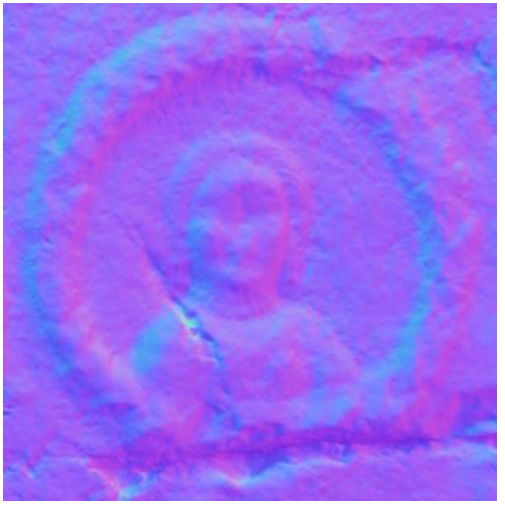

Fig. 15. Kadın büstü detay (RTI)

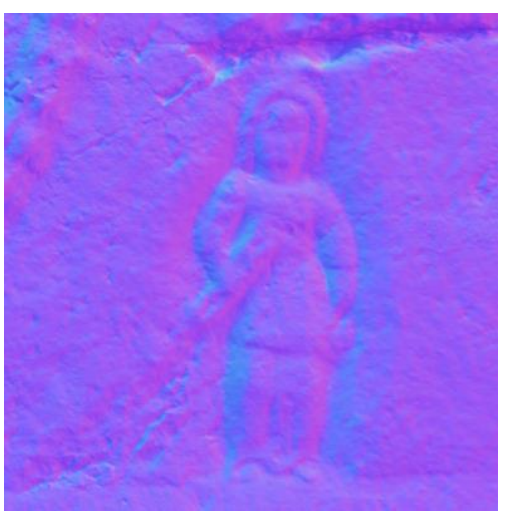

Fig. 16. Kız çocuğu tasviri detay (RTI) betimlemesi yer almaktadır. Genel vucüt hatları dışında detaylı olarak işlenmediği görülen bu figürün altında ise hayvan mücadelesi sahnesine yer verilmiştir. Bir aslan, sol ayağı ile avını yakalamış, duruşu ile uyumlu olarak arka ayakları da hareketli ve mücadele anı ile uyumlu olarak

31 Burada yer verilen yunus balığı tavirleri Antalya Hurma yerleşiminde tespit edilen lahitlerden ikisi üzerinde yer alan, yine tabulanın iki yanına yerleştirilmiş olan yunus balıkları ile oldukça yakın örneklerdir (Krş. Çevik 1995, 56 Fig. 8; 58 Fig. 12). Ayrıca Antalya Doyran - Kartınpınarı yerleşiminde yine aynı kompozisyon içinde tasvir edilen yunus balığı tasvirleri bulunmaktadır (Krş. Çevik 2015, 141). Çelgin tarafından Termessos'ta bir lahdin kapağında yer alan yunus balığı tasviri, kentin nekropolislerindeki başka hiçbir lâhdin kapağında görülmeyen değişik bir özellik olarak değerlendirilir. Söz konusu bezeme lahit kapağının sol alınlığın çukurlaştırılmış alanı içinde bir yunusun üzerine oturmuş, soldan sağa doğru gider vaziyette tasvir edilmiş bir Eros figürünü içermektedir. Bu sahne Çelgin tarafından, yunus balıklarının huzura giden yolda ruhlara rehberlik etmesi şeklinde değerlendirilmiştir, Çelgin 1990, 246, Fig. 432-434.

32 Termessos nekropolisinde tabula ansatanın iki yanında yaprak çelengi içinde büstlerin yer aldığı örnekler için bk. Çelgin 1990, Fig . 445-447-448-449. 
ağzı açık bir şekilde betimlenmiştir. Kuyruğu arka sağ bacağı içinden kıvrılarak geçer ve arkaya doğru savrulur ${ }^{33}$. Aslanın alt ettiği hayvan figürü anlaşılamamakta ancak benzer sahnelerdeki anlatımlara ${ }^{34}$ bakılarak bunun bir boğa olduğu sonucuna varılabilir.

\section{3a. Moles ve Ailesinin Mezar Yazıtı}

Lahit teknesinin ön yüzünde yer alan yuvarlak bir tabula ansata üzerinde 17 satırlık mezar yazıtı tespit edilmiştir.

Harf yüksekliği: 0.026-0.033 m

Tarih: MS III. yüzyıl (Mezar sahibinin taşıdığı Aurelius gens ismi ve harf karakterleri dolayısıyla 212 sonrası)

2

4

6

8

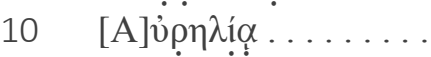

MEI $\Omega \ldots \ldots \ldots . . . .$.

$12 \quad \ldots$. OM ..N.......

$\ldots \ldots \ldots[\dot{\Phi}] \alpha[\sigma \eta \lambda \varepsilon] \imath \tau \tilde{\omega}[v]$

$14 \tau \tilde{\omega} \delta \eta \dot{\mu} \mu * \pi[\varepsilon \vee \tau] \alpha-$

$\kappa \imath \sigma \chi \varepsilon i ́ \lambda \varepsilon 1 \alpha$

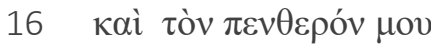

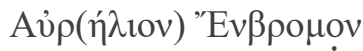

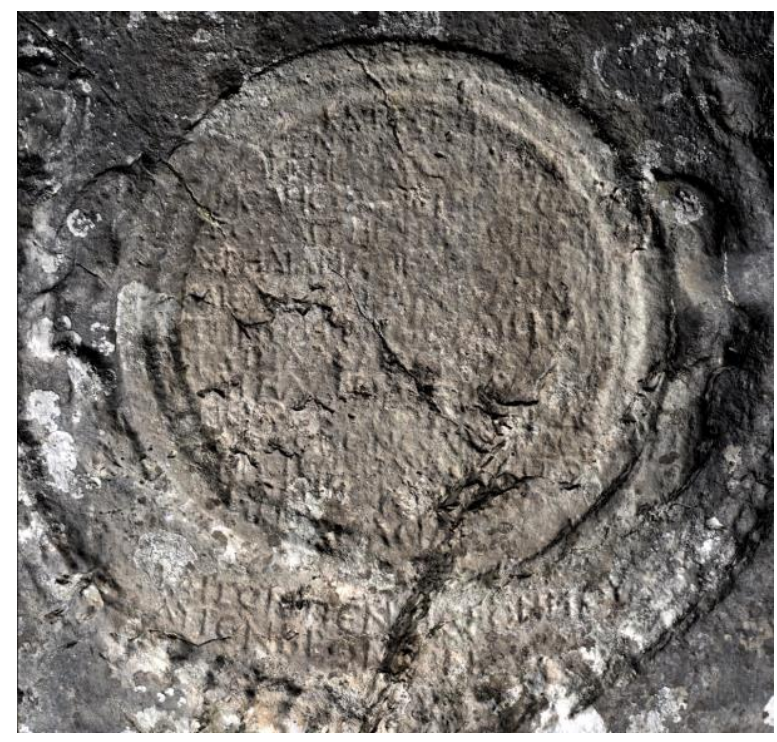

Fig. 17. Yuvarlak tabula içinde Moles ve Ailesinin mezar yazıtı

Bu mezarı, Hermaios olarak da tanınan Marcus Aurelius Moles hem kendisi, hem de karısı falanca kızı Aurelia Ma..... ve kızı Aurelia Na..., gelini falanca kızı Aurelia Tyindara (?) ve de Aurelia falanca için yaptırdı. Phaselis'lilerin halk kasasına beş bin denaria ödeyecek. Ayrıca kayınpeder/kayınbraderim Aurelius Enbromus'un (da buraya gömülmesine izin veriyorum).

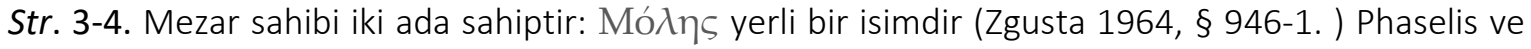
teritoryumunda bu isimde altı farklı kişi belgelenmiştir (TAM II 1210, 1212; SEG VI. 734; LII 1406, 1407; Ormerod - Robinson 1914, 32 nr. 48). 'Epuaĩos ismi de beş farklı kişide belgelenmiştir (SEG LII 1407, 1440, 1444; Ormerod - Robinson 1914, 32 nr. 48).

Str. 6-7. Bu satırlar arasında karısının ve kızının isimleri sıralanmıştır. Her ikisinin de Aurelia gens adları okunabilmesine rağmen nomen'leri okunamamıştır. Altıncı satırda karısının isminden sonra muhtemelen kayınpederinin ismi yazılmıştır. lenmiştir. Ayrıca Hisarçandır'dan Antalya Müzesi'ne getirilen lahit teknesinde de buradaki mücadele sahnesi ile aynı noktada erkek portesinin hemen altında yine aslanın boğayı sol ayağıyla başından yakaladığı sahne tasvir edilmiştir (krş. Öztürk - Atalay 2018 Yayın Aşamasında). 
Str. 8-9. Gelinini belirtmek için yazılmış olan ̀̀ vú $\mu \phi \eta$, bölgede özellikle Olympos yazıtlarında karşımıza çıkar (krş. TAM II 956, 1030, 1060, 1083, 1109). Yazıt üzerinde gelinin adına ilişkin tespit edilen harfleri (TYIN $\triangle$ A.A) içeren kadın isimleri incelendiğinde, bu bölgede Tuv- ve Tut- köküne dayanan iki isimle karşılaşılır. Bunlardan ilki, Phaselis'in önde gelen ailelerinden birinin üyesi olan ve kentin, imparator Hadrianus'un seyahati sırasındaki ziyareti için yaptığı hazırlıklarda önemli rol

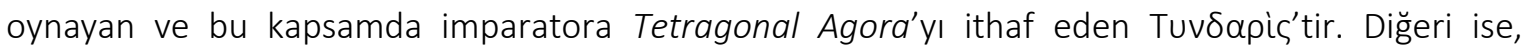
Phaselis teritoryumunda yer alan Hisarçandır'dan ele geçmiş ve henüz yayımlanmamış bir mezar yazııında geçen Tuı $\alpha^{\prime}$ dır. Dolayısıyla buradaki isim için de Tuıv $\delta \alpha[\rho] \alpha$ olarak tamamlama önerisi getirilebilir. Satırın geri kalanında gelininin babasının ismi yer alabilir.

Str. 10. Bu satırda Aurelia gens ismi okunan kadının akrabalık ilişkisi belli değildir.

Str. 13-15. Bu satırlar arasında cezanın ödeneceği kurum ve ceza miktarı aktarılmıştır. Phaselis demos'u bugüne kadar bir tahsilat mercii olarak tespit edilmemiştir ${ }^{35}$. Ceza olarak ödenecek tutarın oldukça yüksek olması dönemin enflasyon oranları ile alakalıdır ${ }^{36}$.

Str. 16-17. Son iki satır sonradan eklenmiş görünmektedir. Burada mezar sahibinin kayınpederi/

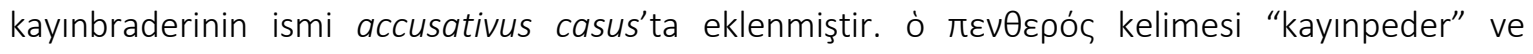
"kayınbirader" anlamlarına gelmektedir". Yerli bir adlandırma olan "Evßpouos ismi, şimdiye kadar sadece Lykia ve Pisidia bölgelerinde belgelenmiştir ve Lykia'da "Е $\mu \beta \rho о \mu о \varsigma$ formu ile de görülür

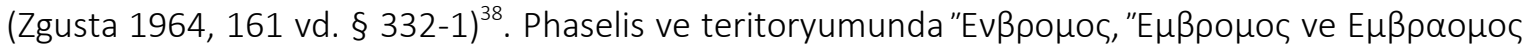
isimlerini taşıyan dokuz kişi bilinmektedir (TAM II 1200, 1206, 1210; SEG LII 1441; LV 1474; ŞahinAdak 2013, 300).

\section{Kırtepe Mevkii II no'lu Podyumlu Lahit Mezar}

Kırtepe mevkiinde bulunan lahit mezar; in-situ podyum ve tekne ile yerinden kay(dırıl)mış kapaktan oluşmaktadır. Mezarın ham maddesi kireçtaşıdır. Podyum blok taşlarla örülmüştür ve çok basamaklıdır, blokların bir kısmı alandaki taş ve toprak dolgusu altında; bir kısmı da dağılmış ve tahrip olmuştur. Tekne podyum üzerinde in-situ konumundadır ancak $1 / 3$ oranında kırıktır bu nedenle ön yüzün sol tarafı hakkında veri alınamamaktadır. Doğu-batı doğrultulu yerleştirilen tekne $1.18 \mathrm{~m}$ en, $2.40 \mathrm{~m}$ boy ve 1.40 m'yükseklik ölçülerindedir. Kapak, tekne üzerinden kay(dırı)mış mezarın $2 \mathrm{~m}$ uzağında yerde ters durmaktadır. Kırma çatı formunda ve köşe akroterli olan kapak $2.58 \mathrm{~m}$ uzunluğundadır, diğer ölçüler alınamamaktadır. Alanın genel görünümünde ciddi bir tahribat görülür (Fig. 6). Mezarın yanından geçen modern yol bu tahribatı arttırmış olmalıdır. Lahit teknesinin iki dar yüzü ve ön uzun yüzü bezenmiş arka yüz yalnızca traşlanarak bırakılmışır. Ön yüzdeki ana sahne sağ kenardan ve üstten, üzüm salkımı ve asma yaprağı taşıyan sarmal dal ile çevrilidir. Teknenin sağ alt köşesindeki amphoraya benzer bir kap içinden çıkarak yükselen tek asma dalı kıvrılarak yükselir ve üst frize bağlanır. Teknenin ortasına kadar -tam olarak tabulayı da ortalayan hizaya kadar- devam eden asma dalı bu noktaya yerleştirilmiş küçük bir amphoranın içine girer. Aynı amphora içinden çıkan başka bir dal bu noktadan itibaren sarmal motifi devam ettirir. Teknedeki kırık nedeniyle ikinci dal kısa bir mesafede izlenebilmektedir. Ancak bu kompozisyondan yola çıkarak teknenin sol alt köşesinden de bir dalın bu noktaya uzandığı açıkça söylenebilir. Böylelikle teknenin iki köşesinden çıkarak yükselen asma dalları üst frize bağlanmış ve tam orta noktada bir amphora içinde buluşmuşlardır (Fig 18).

35 Lykia'da mezara verilecek olan zarara karşı ceza tahsili yapacak kurumlardan biri olarak geçen demos'a yapılan ödemeler hakkında bk. Avcu 2014, 24.

36 Krş. Telmessosluların demos'una yapılan 5000 denarii'lik ödeme: TAM II 51.

37 Liddell - Scott 1999, 619.

38 Hellence'de nasal seslililer olan $v$ ve $\mu$ harflerinin birbirleri yerine kullanılmasına yönelik bkz. Gignac 1976, 119 ve Brixhe 1984, 34. 

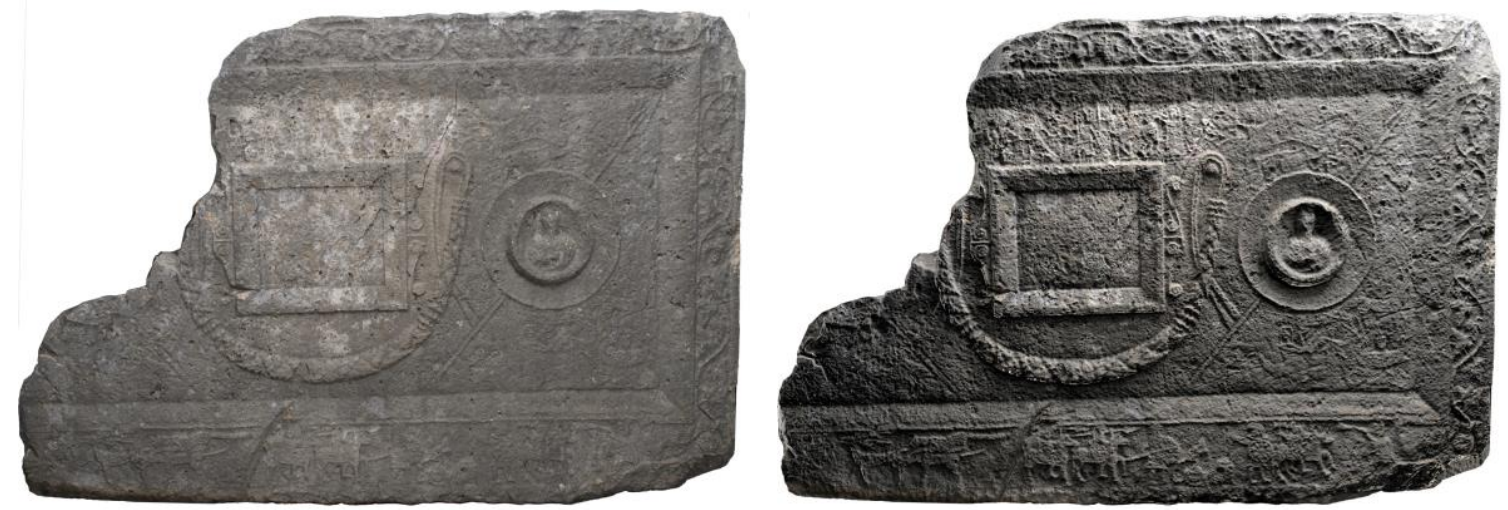

Fig. 18. Kırtepe II no'lu lahit teknesi RTI analizi görüntüleri

Ana sahneyi çevreleyen bezekli frizi tamamlayan alt frizin alanı diğerlerinden daha yüksek tutulmuştur $^{39}$. Burada insan ve hayvan figürlerinin tasvir edildiği görülür. Soldan sağa doğru devam edildiğinde hayvan betimlemeleri ile başlayan kompozisyonun asker tasvirleri ve savaş sahneleri ile devam ettiği görülmektedir. Bu dizilime göre; en solda bir geyik, arkasında onu kovalayan ve yakalamak üzere olan bir köpek (?) ve olasılıkla bir leopar tasvir edilmiştir. Geyik onu kovalayan hayvanlardan kaçmaktayken görülür. Uzun boynuzları arkaya doğru uzanmaktadır. Geyikle aynı hizada ve hemen arkasında olasılıkla bir köpek onu kuyruğundan tutmak üzereyken betimlenmiştir. Köpeğin yanında vücut yapısından anlaşıldığı üzere lepoar olması muhtemel yırtıcı bir hayvan yer alır. Bu yırtıcı tür arka ayaklarını katlayarak çökmüş, kafası öne doğru uzanmış ve uçlara doğru kalınlaşan kuyruğunu arkaya doğru dümdüz açmış olarak görülür. Bu tasvir, hayvanın avına doğru hamle yapmak üzere kendini hazırlamış olduğu anı yansıtmaktadır. Kabartmalar zeminden çok ayrılmayan çizgisel hatlara sahip olduğu için sahneye arkaya doğru derinlik olgusu verilememiş aslında yan yana duran köpek ve leopar üst üste resmedilmiştir (Fig. 19).

Sahnenin devamında tam tabulanın altına denk gelen noktada ardı ardına duran kalkanlı ve mıraklı iki atlı asker yer almaktadır. Askerler sol ellerinde mızrak, sağ ellerinde kalkan taşımaktadır. Mızraklar havaya ve ileri doğru hareketle saldırı anını ifade etmekte kalkanlar atların gövde hizasında tutulmaktadır. Hemen önlerinde antithetik duran iki asker figürü yer alır. Soldan sağa doğru devam edildiğinde ilk asker sağ kolunu geriye doğru atmış dirseğini bükerek elindeki mızrağını bel hizasında çapraz tutmakta, vücudunun arkasında kaldığı için yarım daire şeklinde görülen kalkanını sol elinde üst gövde hizasında taşırken görülür. Karşısında duran asker miğferlidir ve o da sağ elinde çapraz duran mızrak; sol elinde üzeri motifli bir kalkan taşımaktadır ${ }^{40}$. Bu iki figürün arasında yerde duran bir ya da iki figür daha yer alır. Taşın yüzeyindeki tahribat nedeniyle tanımlanamayan bu figürler mücadele sırasında yere düşmüş ölü ya da yaralı kişiler olmalıdır. Sahnenin devamında miğferli askerin hemen arkasında bir atlı asker daha yer alır. Atın yönü önceki atı askerlerle aynı yöndedir ancak asker üst gövdesini ve başını tamamen arkaya çevirmiş sağ elinde taşıdığı çift yönlü baltayı havaya kaldırmış düşmanlarına korku salarken betimlenmektedir.

39 Sarmal dal taşıyan üst friz yük.: $0.11 \mathrm{~m}$ insan ve hayvan figürlerinin tasvir edildiği alt friz $0.19 \mathrm{~m}$ yüksekliğindedir.

40 Söz konusu kalkan motifleri Termessos nekropolisinde bazı mezarlar üzerinde görülmektedir. V. Çelgin tarafından Pisidia Bölgesi ostothek grubuna ve dolayısıyla kalkanlı lahitlere öncülük ettiği düşünülen Alketas Mezarı üzerindeki Mekodanya etkili savaş silahlarının betimlemeleri, gerek İskender'in Asya Seferi gerekse Diadokhoi adı verilen Makedonyalı haleflerinin birbirleriyle yaptıkları mücadeleler sırasında bölge ile olan muhtelif ilişkiler neticesinde Pisidia ve civar bölgelere girmiş ve Termessos'ta da tanınmıştır (Çelgin 1990, 229-234). 
Onun hemen yanında yönünü savaş sahnesine doğru çevirmiş ayakta duran bir başka figür elinde ağız hizasında havaya kaldırmış olduğu, uca doğru genişleyen konik formda bir müzik enstrümanı çaldığı an içinde tasvir edilmektedir. Figür, sırtından diz kapaklarının altına kadar dökülen pelerin benzeri bir giysi giymektedir. Savaş alanında ordunun disiplinini sağlayacak komutları lejyona iletmekle görevli tubicenler görev yapmaktaydı ${ }^{41}$. Buradaki sahne üzerinde tasvir edilen kişi söz konusu savaş düzeni içinde görevini yerine getiren tuba çalan bir tubicen olarak nitelendirilebilir. Zira içinde bulunduğu kompozisyon ve elindeki müzik aletinin formu ve onu savaş sahnesi içinde çalarken betimlenmiş olması bu savı destekler nitelikte bir görsel ortaya koymaktadır. Alt friz, tasvir edilen bu figür ile son bulmaktadır (Fig 19).
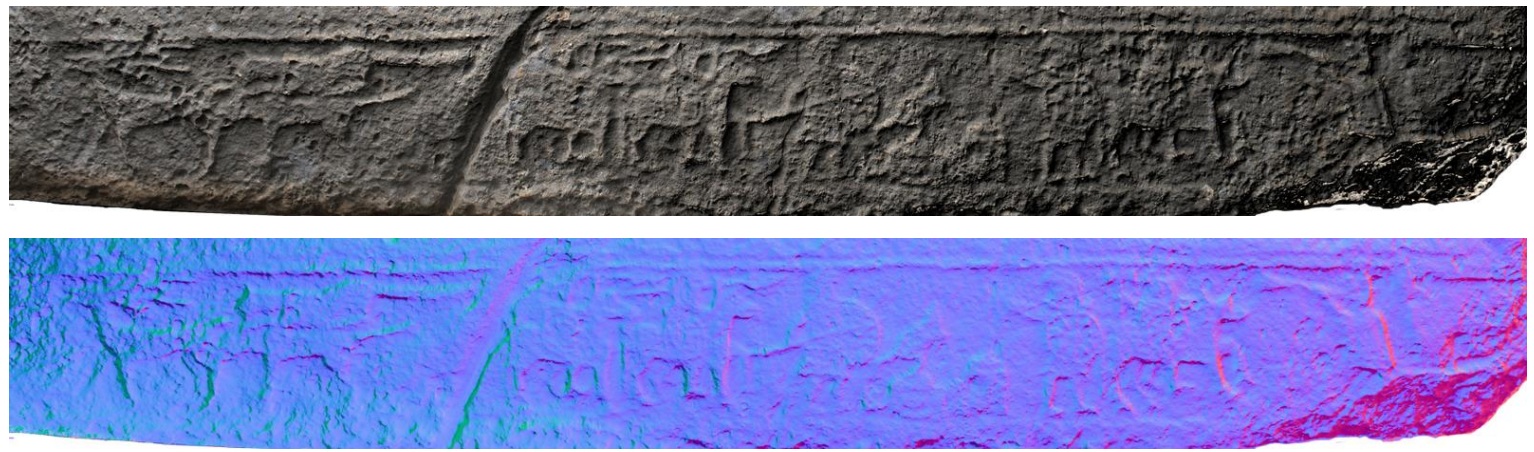

Fig. 19. Kırtepe II no'lu lahit teknesi alt friz solda hayvan mücadelesi ve sağda savaş sahnesi RTI görüntüleri

Frizi süsleyen savaş sahnesi ve asker figürleri mezar sahibinin savaşlarda görev yapmış bir asker olması ya da eğer ordu ve savaşla ilgisi olmayan bir vatandaş ise bu sahneleri betimleterek kendini yüceltmek istemesi ile açıklanabilir. Tekne ön yüzündeki tabula üzerine uygulanan RTI metoduna rağmen hiçbir harf kalıntısına rastlanmamış olması buradaki yazııın silinmiş olmasından ziyade yazılmadan bırakılmış olduğununa işaret etmektedir. Dolayısıyla burada gömülü olan kişinin statüsüne ilişkin net bir tanımlama yapılamamaktadır. Bununla birlikte bölgede MS II.-IV. yüzyıl arasında yaşanan eşkıya faaliyetleri ve bunlara karşı alınan önlemler diğer epigrafik verilerden bilindiğinden mezar sahibi kişinin de böyle bir görev içinde bulunmuş olabileceği dönemsel olarak uyuştuğu için göz ardı edilmemelidir ${ }^{42}$.

Teknenin ön uzun yüzündeki ana sahnenin merkezinde dikdörtgen bir tabula ve onu çevreleyen tek girland yer almaktadır. Yapraklardan (meşe?) oluşan girlandın ortasında dört yaprakıı bir çiçek ${ }^{43}$ motifi yer alır ve yaprakların arasından geçen taenialar girlandı sarmaktadır. Uçlara doğru incelen girland taenialarla çivilere asılmış, sarkan taenia uçları girland arkasından geçerek dışa doğru kıvrıımıştır. Tabula ansatanın sağında kalkan ve mızrak içinde erkek figürü yer almaktadır. Figürün genel vücut hatları belirgin ancak yüz ve giysi detayları tahribat nedeniyle belirsizdir. Tabula ansatanın

Roma ordusunda tuba, cornu ve bucina olarak adlandırılan üç ana estrüman bulunmaktadır. Bu enstrümanlardan kavisli bir yapıya sahip cornuya nazaran ince uzun yapısıyla kuvvetli bir sese sahip olan tubayı çalmakla görevli kişilere tubicen denilmektedir. Konuyla ilgili detaylı bilgi için bk. Southern, 2007, 159; Mezar steli üzerinde elinde tuba ile betimlenmiş tubicen örneği için bk. Alexandrescu 2008, 172 vd. Fig. 2-3.

42 Bölgede yaşanan eşkiya faliyetleri bunlarla mücadeleye ilişkin kırsal alan güvenliği hususunda bk. Öztürk 2006.

43 Roma İmparatorluğu içinde bölgeler ötesi önem taşıyan lahit üretim merkezleri arasında Roma ve Atina'nın yanı sıra bir de Dokimeion vardı. Burada yapılan lahitler, eski ticaret yolları boyunca Anadolu' da yayılmıştı ve yerel lahitlerin tersine- büyük miktarlarda ihraç edilirdi. Bu nedenle, lahitlerle ilgili olarak ' Anadolu ana üretimi' diye bir şeyden söz edebiliriz. Bu merkezdeki girlandlı lahitlerde orta yerleri bir çiçekle vurgulanmış örnekler vardır, Koch 2011, 165. 
solunda muhtemel bir kadın figürü yer alıyor olmalıydı; ancak bu bölüm kırık ve eksiktir.
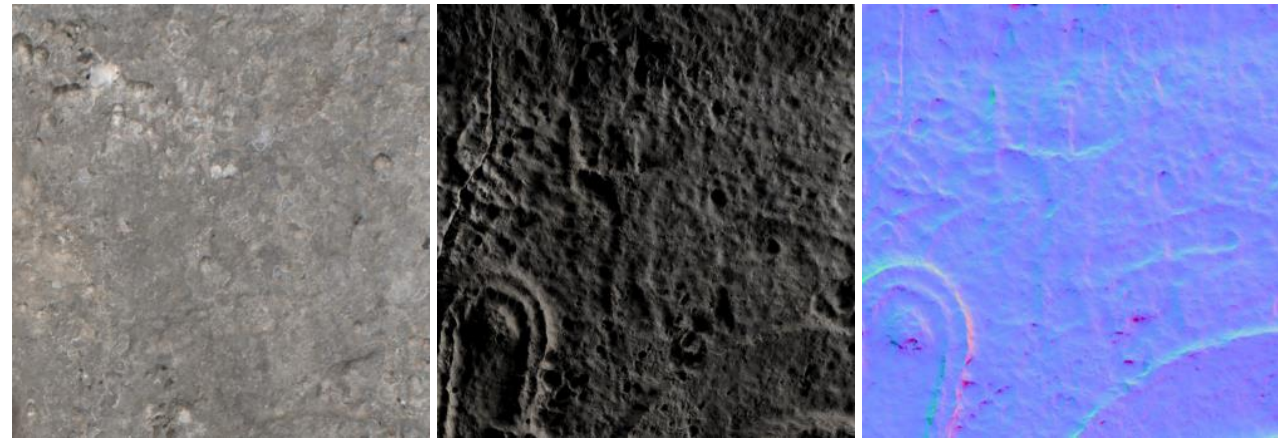

Fig. 20. Kırtepe II no'lu lahit teknesi, kalkanın sol üst köşesinde yer alan insan figürünün RTI metodu ile ortaya çıkan görüntüleri (default, diffuse gain, normals)

Bu mezara ilişkin bahsi geçen tüm kabartmalar haricinde, çıplak gözle görmenin neredeyse imkansız olduğu oldukça yüzeysel hatlarla tekne yüzeyine işlenmiş başka figürler de bulunmaktadır. Bu figürler tam tabulanın üst silme çizgisi üzerinde yan yana bulunan tasvirlerdir. İçlerinden bir tanesi bu diziden biraz ayrı kalkanın sol kenarı üzerinde yer almaktadır. Çizgisel hatlarla belirtilmiş olan figür kollarını iki yanda havaya doğru kaldırmış olasılıkla bir erkek ait tasviridir (Fig 20). Üst gövdesi bele doğru daralan bir yapıda olan figürün gerek duruşu gerekse vücut hatları, vazo resim sanatı üzerinde tasvir edilen ekphora sahnelerinin içinde ağıt yakan insanların duruşuna benzer bir izlenim vermektedir ${ }^{44}$. Ekphora sahnelerindeki kişiler elleri başlarının üzerinde birleştirmiş olarak tasvir edilmiştir. Bu nedenle lahit üzerinde betimlenen tasvir ile birebir örtüşen bir betimden söz edilemese de figürün vücut hatları ve kollarının duruşu ilk izlenimde ölü kültü ritüellerinde gördügümüz figürleri anımsatmaktadır.Buradaki tasvir de yine ölü kültü ile ilişkili bir feryat anı veya sesleniş halindeyken tasvir edilmiş olabilir. Tabulanın üst çizgisinde ardı ardına bulunan figürler ise çok silik figürler olmasına rağmen izlenbilen genel hatları ile şu şekilde özetlenebilir; soldan sağa doğru gelindiğinde ilk figür, mızrak olabilecek uzun bir objeyi bel hizasında tutan bir bacağı gergin öne doğru atılmış diğer bacak dizden kırılmış bir hareket halinde olan erkek figürü, hemen önünde bir başka ayakta duran insan figürü, onun yanında atı ile çok yakın tasvir edilen bir kolunu dirsekten kırarak havaya kaldırmış diğer elinde kalkan tutan figür ve hemen yanında yüzü sahibine dönük at figürü ve son olarak bileklerine kadar uzanan bir elbise içinde, saç ya da giysi örtüsünün hatları başın etrafını çevreleyen bir kadın figürü yer almaktadır. Bu figürler mezara uyguladığımız RTI metodu sayesinde görünür kılınmıştır (Fig. 21) ancak ileride farklı görüntüleme metotlarının denenmesiyle birlikte daha net verilere ulaşılabilceği düşünülmektedir. Teknenin her iki dar yüzünde de kalkan ve

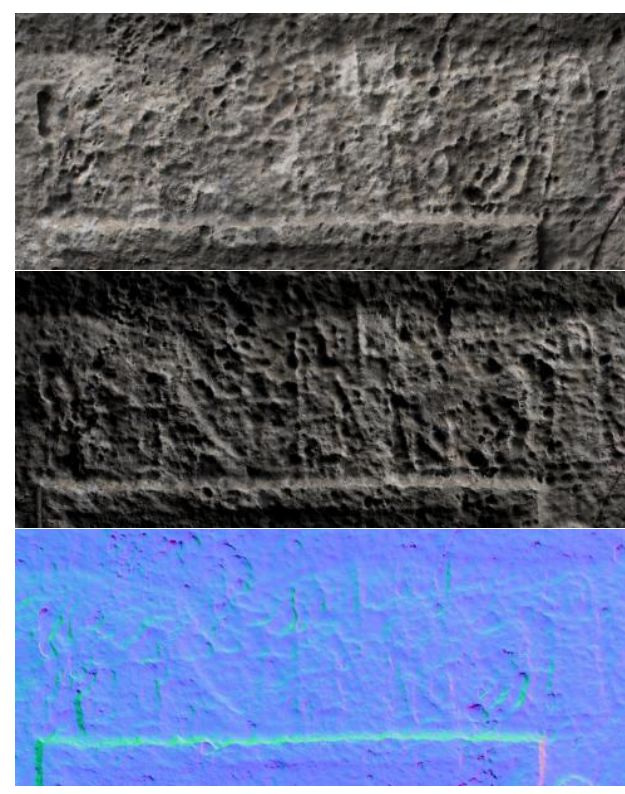

Fig. 21. Kırtepe II no'lu lahit teknesi tabula üstünde yer alan oldukça silik tasvirlerin

RTI görüntüleri

44 Ekphora sahnesinin seramikler üzerindeki tasvirleri için bk. Boardman 2016, 34 Fig. 44, 35 Fig. 45; Akçay 2017, 205 Fig. 24, 208 Fig. 30, 209 Fig. 32. 
içinden geçen mızrak kabartması yer alır. Tekne içinde yer alan doğu yönde gömünün başının yerleştirildiği yastık bölümü 0.38 m uzunluğunda hafif̧̧e yüksek bırakılmıştır.

\section{Değerlendirme ve Sonuç}

Yaylakuzdere Mevkii'nde yer alan yalnızca kapağın bir bölümüne ulaştığımız mezar mevcutta elde ettiğimiz arkeolojik materyal verilerin eksikliği nedeniyle sadece epigrafik olarak değerlendirilmiştir. Söz konusu mezar kapağı Lykia bölgesindeki yaygın kullanımı ile bölgeyle özdeşleşen semerdam formunda üretilmiştir ve mezar yazıtı semerdam kapağın dar yüzüne kazınmıştır ${ }^{45}$.

Bunun dışında arkeolojik olarak değerlendirmesi yapılan diğer üç adet lahit mezar Phaselis Teritoryum sınırlarına dahil olan dağıık bir coğrafyada yer almaktadır. Söz konusu eserler kent merkezlerine uzak küçük çiftlik yerleşimleri ve yakınlarında kullanılmış olmalarına rağmen gerek mimari özellikleri gerekse donatılıkları bezeme unsurları ile üretimleri çağdaş olan kent yerleşimlerindeki lahit mezarlar ile benzer özellikler yansıtmaktadırlar. Bunun yanı sıra Roma Atina ve Dokimeion gibi önemli lahit üretim merkezlerinde üretimin hız kazandığı MS II. ve III. yüzyıllar çalışmada yer alan lahitleri tarihlendirdiğimiz dönem aralığı ile örtüşsmektedir ${ }^{46}$.

Blok taşlarla örülmüş podyumlar üzerinde yükselen söz konusu mezarlar kireçtaşı malzemeden üretilmiştir ve konumlandırılmalarında doğu-batı yönünün tercih edildiği bir yön birliği söz konusudur. Teknelerin tümünde ön uzun yüz çeşitli kabartmalarla bezenmiştir. Bu sahnelerde mezar sahiplerinin büstleri, av sahnesi, savaş sahnesi, aslan boğa mücadelesi, geyik ve onu avlayan av köpeği, yaban keçisi ve yırtıcı hayvan tasvirleri ile doğadan unsurların kullanıldığı kompozisyonlar yer almaktadır. Mezar sahiplerinin yaşamlarından izler taşıyan bu sahnelerde -ölü gömme geleneklerinin bir parçası olarak mezar sanatı içinde- hayvan tasvirlerine de ağılıklı olarak yer verilmesi kırsal yaşamın etkileri olarak değerlendirilebilir.

Kabartmaların, zeminden çok ayrılmayan ve yüksek plastik özellik göstermeyen işçiliklerle oluşturulduğu görülür. Söz konusu mezarlardaki tasvirler genel görünümleri ile farklı kompozisyonlar oluşturmuş olsa da detaylarda benzer unsurlar barındırdıkları tespit edilebilmektedir. Teknelerin ön yüzündeki ana sahnenin üzüm salkımı ve asma yaprağı taşıyan sarmal bir friz kuşağıyla çevrelenmesi üç mezarda da görülen ortak bir özelliktir. Asıl olarak bereketi sembolize eden asma dalları, yeni dünyasında var olmaya devam edeceğine inanılan ruhun ölümsüzlüğünü de temsil etmektedir ${ }^{47}$. Söz konusu bitki sarmalı Attaleia'ya bağlı Hurma ${ }^{48}$ yerleşimindeki lahitlerde ve Hisarçandır'da bulunarak Antalya Müzesi bahçesine getirilen lahit teknesinde de görülür. Bu örnekler bezeğin gerek tasviri gerekse kullanım şeması açısından örtüştüğü betimlemelerdir.

Kırtepe mevkiinde bulunan lahit teknelerinde tabulayı çevreleyen, tek girland yer almaktadır. Bu kompozisyon ender görülen bir düzenleme olarak nitelendirilebilir. Zira Imparatorluk Dönemi girlandlı lahit tipolojisinde yalnızca tabulayı çevreleyen tek girland tasviri gruplar içinde yer almamaktadır $^{49}$. Anadolu örneklerine bakıldığında lahitlerin çoğunluğu, orta yerinde genellikle ufak bir levha bulunan üç girlandlı lahitler ve orta girlandın geleceği yere büyük bir levhanın yerleştiril-

Lykia Bölgesi'nde sıklıkla kullanılan semerdamlı kapaklar hakkında ayrıntılı bilgi için bk. İil 1996, 8-9; Koch 2001, 254-256.

46 Koch tarafından II ve III. yüzyıllar özellikle kabartmalı lahitlerdeki ana üretimin en zengin olduğu dönem aralı̆ı olarak ele alınmaktadır, Koch 2001, 93.

47 Çelgin 1990, 328

48 Çevik 1995, 43 vd. Fig. 9, 8, 12, 13.

49 Koch 2011, 207. 
diği iki girlandlı lahitler olarak görülmektedir. Bu kompozisyon Hurma yerleşimi ${ }^{50}$ kalıntıları, Hisarçandır ${ }^{51}$, Doyran ${ }^{52}$ ve Typallia ${ }^{53}$ keşfedilen lahitler üzerinde yer alan girland tasvirleri ile yakın benzerlik içindedir. Antalya Müzesi bahçesinde sergilenen Hisarçandır lahdi, tabulayı çevreleyen tek girlandın ortasından sarkan üzüm salkımı ${ }^{54}$ ve Uzuntaş mevkiindeki girland kavsinin ortasındaki çiçek vurgusu ${ }^{55}$ Roma imparatorluk Dönemi girlandlı lahitlerine bir gönderme yaparak aslında bu çalışmada ve Hurma yerleşiminde yer alan lahitlerin bezeme unsurlarının var oluşunda dönemin sanat örneklerinin bilindiğini de ifade etmektedir. Analoji örnekleriyle yapılan karşılaştırmalarda benzerlikleriyle dikkati çeken bezeme örgelerinden biri de sahnelerde balık tasvirlerine yer verilmesidir. Kırtepe'de, kuyrukları birbirine değecek şekilde tabulanın iki yanına ansata yerine yerleştirilmiş ikişer adet yunus balığı betimlemesi $\operatorname{Hurma}^{56}$ tespit edilen lahitlerden ikisi üzerinde ve Kartınpınarı'nda ${ }^{57}$ bir lahit üzerinde yer alan yunus balıkları ile gerek tasvirleri gerekse yerleştirilme şeması açısından örtüşen örneklerdir. Ayrıca Beşiktaş'ta lahdin ön yüzünde sol alt köşede yer alan dağ keçisi Hisarçandır'daki ${ }^{58}$ lahit üzerinde de betimlenen bir figürdür.

Girlandın iki yanında yer alan portreler ise (bir mezarda yapraklı çelenk ve yuvarlak çerçeve diğer ikisinde kalkan içinde) Roma mezar sanatının yanı sıra Pisidia ${ }^{59}$ bölgesi mezar sanatı etkilerinin bölgeye nüfuz ettiğini gösteren bir diğer özellik olarak değerlendirilmektedir. Ayrıca MS. I. yüzyıldan itibaren çeşitli gömü kapları veya mezar anıtları üzerinde görülmeye başlanan portreler III. yüzyıla gelindiğinde lahitlerin kronolojik sıralamasında portrelerden yararlanılacak ölçüde artmıştır ${ }^{60}$. Resmi kimliği olmayan kişilerin imparatorlara ya da yönetici sınıfın aile üyelerine öykünerek kendilerini tasvir ettirdiği de görülmektedir. Büyük merkezler dışında eyaletler söz konusu olduğunda portreler daha belirsiz işlenmektedirler ${ }^{61}$. Taşlardaki deformasyon nedeniyle yüz detaylarını tam göremiyor olsak da alçak kabartma olarak işlenen portrelerin, arkasında hatırasını

Çevik 1995, 56 Fig. 7; s. 58 Fig. 11; Aynı yayında Hurma'nın batısındaki Hisarçandır'da yer alan üç lahdin görselleri de eklenmiştir. Bu örnekler de tabulanın etrafını üç yandan çevreleyen tek kavisli girland kompozisyonunu taşımaktadırlar bk. 61 Fig. 19-20.

51 Antalya Müzesi'nin bahçesinde getirilen eser Öztürk - Atalay 2018 tarafından yayına hazırlanmaktadır.

52 Çevik 2008, 223 Fig. 4

53 Çevik 2015, 503

54 Roma Imparatorluk Dönemi lahitlerinde Dionysos anlatımlı lahit grupları içinde üzüm asmaları ya da girlandlar üzerine takılmış üzüm salkımları kullanılmaktaydı bezeğin lahitler üzerinde kullanımı için bk. Koch 2001, 150, 165, 204, 211, 249.

55 Roma İmparatorluk Dönemi Küçük Asya girlandlı lahitlerinde girlandın ortasına yerleştirilen çiçek motifi ile karşılaşılmaktadır. Örnekler için bk. Koch 2010 içinde; Perge: 101 Fig. 1 ve 119 Fig 53; Efes; 111 Fig. 27; Kilikia Uzuncaburç: 120 Fig. 55; Augusta: 120 Fig. 58.

56 Çevik 1995, 56 Fig. 8; 58 Fig. 12.

57 Çevik 2015, 141

58 Hisaçandır'daki keçi figürü kendisini avlamak isteyen kişinin mızrağı üzerine doğrultulmuşken ön ayakları üzerinde kalkmış olarak betimlenmiştir, bk. Çevik 1995, 61 Fig. 18

59 Termessos nekropolislerinde yer alan kalkanlı lahit grubunun en karakteristik örneklerinde, teknelerin ön uzun yüzlerinde, ortada yazıt taşıyan bir tabula ansata, bunun iki yanında kabartma halinde birer yuvarlak kalkan tasviri (Fig. 294-301); yan (kısa) yüzlerinde de aynı şekilde, konturlarını kare, ya da dikdörtgen biçiminde birer çerçevenin oluşturduğu, yüzeyleri çukurlaştırılmış panolar içinde, gene kabartma halinde birer yuvarlak kalkan tasviri (Fig. 300-304) kapsamaktadır ayrıntılı bilgi için bk. Çelgin 1990, 207.

60 "birer yuvarlak kalkan tasviri (Fig. 300-304.) kapsamaktadır.

60 Çelgin 1990, 207. "Frizli lahitlerde, girlandlılarda ya da uçan Erosları veya Nikeleri ve bir ara motifi gösterenlerde portre yapımına gidilmiştir. Birkaç örnekte de kapak üzerinde bir tonda ya da çelenk içinde portre bulunduğu bilinir. MS III. yüzyılda portre kullanımı artmıştır". Koch 2001, 68-74.

61 Koch 2001, 69. 
yaşatacak izler bırakmayı isteyen mezar sahiplerinin gerçekçi anlatımlarla tasvir edilmiş izleri olarak değerlendirilebilir.

Teknelerinin hepsinde arka uzun yüzlerin sadece traşlanarak bırakıldığı görülmektedir. Yan yüzlere bakıldığında ise Beşiktaş'taki teknenin dar yüzlerinde kalkan ve ortasından çapraz geçen mızrak tasvirleri ve kalkanların merkezine bir dar yüzde çiçek diğerinde erkek büstü yerleştirilmiştir. Ayrıca Beşiktaş mevkiindeki mezarın kapağında da kalkanlar yer alır. Kırma çatı formundaki kapağın iki alınlığında da ortası çiçek motifli birer kalkan betimlenmiştir. Uzuntaş'ta ise yine dar yüzlerde kalkan ve içinden geçen mırak tasvir edilmiştir. Bu iki lahitlerde ön yüzlerdeki insan büstleri de yine kalkan içinde betimlenmiştir. Ayrıca çalışmaya konu edilen lahitlerde gerek tekne üzerindeki ana sahne içinde gerekse kapak üzerinde yüksek kabartma olarak aslan boğa mücadelesinin tasvir edilmesi bölge mezar sanatında Kuzey Lykia ve Doğu Lykia etkilerinin varlığını gösterse de Pisidia bölgesi ile bütünleşen kalkan tasvirli lahitlerin etkisinin baskın izleri mezarlar üzerinde izlenebilmektedir. Termessos nekropolislerinde serbest duran lahit tipleri içinde kalkanlı lahitler esas mezar grubunu oluşturmaktadır, Termessos dolayısıyla Pisidia bölgesi mezar sanatının çalışmada yer verilen lahitlerin yer aldığı coğrafyayı etkilmiş olduğu açıktır ${ }^{62}$.

Makalede yer verilen ve epigrafik verilerle Phaselis'e bağlı yerleşimlerin sakinlerine ait oldukları belgelenen mezarlar ile bezeme unsurları açısından anoloji örneklerinden olan Hurma, Hisarçandır ve Typallia yerleşimlerindeki lahit mezarlar üzerindeki tasvirler, Çandır Vadisi boyunca benzer ikonografilerle oluşturulmuş bir mezar sanatı şeması ortaya koymaktadır. Farklı lokalizasyonlarda bulunan bu lahitleri süsleyen bezeme örgelerinin, alışlagelmiş genel tipolojiden ayrıldıkları noktalarda birbirlerine benzer özellikleri yansıtmaları dikkat çekidir. Phaselis kent merkezindeki nekropolislerinde yapılan araştırmalarda teritoryum sınırlarında belgelediğimiz lahitler üzerinde yer alan ikonografik unsurların birarada resmedildiği bir mezar şimdiye değin tespit edilmemiştir ${ }^{63}$. Lahitlerin yer aldığı Çandır Vadisi, Phaselis teritoryumunun batı sınırının uzandığı bölgedir. Söz konusu coğrafya Lykia, Pamphylia ve Pisidia bölgelerinin buluşma noktası olduğu için farklı kültürlerin izlerini bir arada görmek şaşırtıcı değildir. Ancak kırsal olarak nitelendirebileceğimiz bu alanlarda lahitlerin bu denli zengin ikonografik öğelerle süslenmesi bazen kent merkezlerinde dahi karşılaşılmayan bir durum olarak ilgi çekicidir. Yukarıda bahsedildiği üzere, işlenen öğelerin büyük lahit üretim atölyelerinin izlerini taşıması ve kırsal kültüre dair tasvirleri içermesinin yanı sıra coğrafi konumları itibarıyla farklı bölge kültürlerinin etkisine açık bir mezar sanatı olduğundan söz etmek mümkündür.

Çalışmada, teknolojinin bilime sunduğu yeni görüntüleme metotlarından RTI'ın, arkeolojik ve epigrafik verilerin analiz sürecinde yorumlanmasına pozitif katkılar sağlayan bir metot olduğu açıkça görülebilmektedir. Lahitler üzerinde RTI metodunun sunduğu algoritmik görüntüleme filtrelerinden özellikle specular enhancement modunun yazıt karakterleri gibi insizasyonun bulunduğu noktalarda diffuse gain'in ise rölyeflerde görsel algıyı artırarak analiz sürecine önemli derecede katkıda bulunduğu gözlemlenmiştir. Bunun yanı sıra lahitler üzerinde gerçekleştirdğimiz tahribatsız

62 Termesos'taki lahitler içinde büyük çoğunluğu teşkil eden ve bu suretle grubun en karakteristik örnekleri olma niteliğini taşıyan, nekropolislerdeki bütün lahit tipleri içinde en sık rastlanan, en karakteristik ve en homojen grubu meydana getiren çerçeveli yuvarlak kalkan tasvirli lahitlerdir. Bu grupta; tekneler esas uzun yüzlerinde, ortada tabula ansata, bunun iki yanında, kabartma halinde birer yuvarlak kalkan tasviri (Fig. 294-301); yan (kısa) yüzlerinde de aynı şekilde, kabartma halinde birer yuvarlak kalkan tasviri (Fig. 300-304) yer almaktadır. Yine bu karakteristik örnekler arasında yer alan bazı lahitlerin teknelerinin sadece bir uzun yüzlerinin işlendiği, yani tek cepheli olarak meydana getirildiği görülmektedir (Fig. 305-307), Çelgin 1990, 207.

63 Gürel 2016, 279-297. 
ve temassız belgeleme çalışmaları ile sonuçların elde edilmiş olması da kültür mirasımızın korunması açısından oldukça önemlidir. Ayrıca direkt analizle ya da bilinen yöntemlerle yapılan çalışmalarla elde edilmesi neredeyse imkansız olan materyal kültür kalıntıları üzerindeki verilerin, hassas ve doğru bir biçimde belgelendiği takdirde bizlere ne ölçüde veri sunabileceği yukarıda bahsi geçen analiz çalışmaları sonucunda ortaya koyulmuştur. 


\section{BİBLIYOgRAFYA}

\section{Antik Kaynaklar}

Aristot. Oecon

\section{Modern Literatür}

Adak et al. 2006

Alexandrescu 2008

Akçay 2016

Akçay 2017

Arslan - Tüner Önen 2016a

Arslan - Tüner Önen 2016b

Arslan - Tüner Önen 2017

Avcu 2014

Barbosa 2009

Bartoněk 1966

Belli 1981

Béthoux et al. 2016

Blackman 1981

Boardman 2016

Brixhe 1984

Çevik 1995

Çevik 1999

Çevik 2008
(= Aristoteles, Oeconomica). Kullanılan Metin: Aristoteles, Oeconomica. Eds. B. A. van Groningen and A. Wartelle. Aristotle Economique. Paris, Les Belles Lettres (1968) 1-35. (1343a1-1353b27).

M. Adak, N. Tüner Önen - S. Şahin, "Neue Inschriften aus Phaselis". Gephyra 2 (2006) 1-20.

C. G. Alexandrescu, "Archaeological Finds of "Brass" Instruments in Funerary Contexts". Hrsg. E. Hickmann, A. A. Both, L. Koch - R. Eichmann, Orient Archäologie 22, Studien zur Musikarchäologie VI (2006)163-78.

A. Akçay "Epigrafi Araştırmalarında Yeni Bir Belgeleme ve Analiz Metodu Olarak RTI". MJH VI/2 (2016) 1-16. Doi: 10.13114/MJH.2016.285.

T. Akçay, Yunan ve Roma'da Ölü Kültü. Ankara 2017.

M. Arslan - N. Tüner Önen, "2015 Yılı Phaselis Antik Kenti ve Teritoryumu Yüzey Araştırması”. AST 34/1 (2016) 355-368.

M. Arslan - N. Tüner Önen, "Phaselis". Ed. H. İskan - E. Dündar, Lukka'dan Likya'ya Sarpedon ve Aziz Nikolaos'un Ülkesi (2016) 300-317.

M. Arslan - N. Tüner Önen, "Phaselis ve Teritoryumu Yüzey Araştırması 2016". Anmed 15 (2017) 213-223.

F. Avcu, Lykia Bölgesi Mezar Yazıtlarında Mezar Cezaları ve Ceza Tahsilat Kurumları. Yayımlanmamış Yüksek Lisans Tezi, Akdeniz Üniversitesi. Antalya 2014.

J. C. G. C. Barbosa. RTI-Based Techniques and Tools for Digital Surrogates. Master Thesis. Universidade do Minho, Portugal 2009.

A. Bartoněk, Development of the Long-Vowel System in Ancient Greek Dialects. Praha 1966.

O. Belli, "Urartular'da Hayat Ağacı İnancı". Anadolu Araştırmaları 8 (1982) 237-247.

O. Béthoux, A. Llamosi, S. Toussaint. "016 Reinvestigation of Protelytron permianum (Insecta; Early Permian; USA) as an example for applying reflectance transformation imaging to insect imprint fossils". FossRec 20 (2016) 1-7. Doi: 10.5194/fr-20-1-2016, 2016.

D. J. Blackman, "The Inscriptions". Ed. J. Schäfer, Phaselis. Beiträge zur Topographie und Geschichte der Stadt und ihrer Häfen, Tübingen (1981) 138-163.

J. Boardman, Erken Yunan Vazo Ressamlığı. İstanbul 2016.

C. Brixhe, Essai sur le Grec Anatolien au début de Notre ère, Nancy 1984.

N. Çevik "Antalya - Hurma Köyü'nde bir Çiftlik Yerleşimi”. Lykia Anadolu Akdeniz Kültürleri (1995) 39-61.

N. Çevik "Hayat Ağacının Urartu Kült Törenlerindeki Yeri ve Kullanım Biçimi". Anadolu Araştırmaları XV (1999) 335-367.

N. Çevik, "Northeast Lycia. The New Evidence - Results from the past ten years from the Bey Mountains Surface Surveys". Adalya XI (2008) 189-233. 
Çevik 2015

Davies 1895

Diaz-Guardamino- Wheatley 2013

Diaz-Guardamino et al. 2015

Duffy 2010

Durukan, 2007

Frood - Howley 2014

Gignac 1976

Hameeuw 2016

İdil 1998

Karaüzüm 2005

Kızgut - Bulut - Çevik 2009

Kleinitz 2012

Kleinitz 2013

Koch 2001

Koch 2010

Köroğlu 1996
N. Çevik. Lykia Kitabı. Antalya 2015.

G. Davies, "Greek Inscriptions from Lycia". JHS 15 (1895) 100-115.

M. Diaz-Guardamino - D. Wheatley. "Rock Art and Digital Technologies: The Application of Reflectance Transformation Imaging (RTI) and 3D Laser Scanning to the Study of Late Bronze Age Iberian Stelae". MENGA: Journal of Andalusian Prehistory 4 (2013) 187-203.

M. Díaz-Guardamino, L. G. Sanjuán, D. Wheatley, V. R.Z amora. "RTI and the study of engraved rock art: A re-examination of the Iberian southwestern stelae of Setefilla and Almadén de la Plata 2 (Seville, Spain)". Digital Applications in Archaeology and Cultural Heritage 2 (2015) 41-54. Doi: 10.1016/j.daach.2015.07.002

M. S. Duffy, "Polynomial Texture Mapping at Roughting Linn Rock Art Site". ISPRS Technical Commission V Mid-Term Symposium 38/5. Newcastle, UK (2010) 213-217.

M. Durukan, "Dead Cult in Olba Region During Hellenistic and Roman Periods". Anatolia Antiqua XV (2007) 147-164.

E. Frood - K. Howley, "Applications of Reftlectance Transformation Imaging (RTI) in the study of temple graffiti". Eds. E. Pischikova, J. Budka, K. Griffin, Thebes in the First Millenium BC. Cambridge (2014) 625-638.

F. T. Gignac, A Grammar of the Greek Papyri of the Roman and Byzantine Periods: Phonology, Vol. I. Milano 1976.

H. Hameeuw, A. Devillers - W. Claes, "Relighting Egyptian Rock Art: Rapid, Accurate HD Imaging of Prehistoric Petroglyphs". Zenodo (2016) 1-11. Doi: 10.5281/zenodo.48060

V. İil. Likya Lahitleri. Ankara 1998.

G. Karaüzüm "Doğu Dağlık Kilikia (Olba) Bölgesi Lahitleri" Yayımlanmamış Yüksek Lisans Tezi, Mersin Üniversitesi, Arkeoloji Bölümü. 2005

i. Kızgut, S. Bulut - N. Çevik, "An East Lycian City: Idebessos". Adalya XII (2009) 145-172.

C. Kleinitz. "Reflectance Transformation Imaging (RTI) in der Bestandsdokumentation der Sekundärbilder und -inschriften von Musawwarat es Sufra im Rahmen des Musawwarat Graffiti Project". Der Antike Sudan. Mitteilungen der Sudanarchäologischen Gesellschaft zu Berlin 23 (2012) 7-20.

C. Kleinitz. "Die Sekundärbilder und -inschriften der Großen Anlage von Musawwarat es Sufra und das Musawwarat Graffiti Project". Eds. St. Wenig, K. Zibelius-Chen, Die Kulturen Nubiens, ein afrikanisches Vermächtnis. Dettelbach. Deutschland (2013) 399-413.

G. Koch. Roma Imparatorluk Dönemi Lahitleri. Arkeoloji ve Sanat Yayınları İstanbul 2001.

G. Koch, Türkiye'deki Roma Imparatorluk Dönemi Lahitleri. Eds. K. Dörtlük, T. Kahya, R. Boyraz Seyhan - T. Ertekin. Çev. Burhan Varkıvanç. Suna - Inan Kıraç Akdeniz Medeniyetleri Araştırma Enstitüsü Monografi Dizisi 5 (2001) Antalya.

H. Köroğlu, Frigler'de Hayat Ağacı Inancı. Yayımlanmamış Yüksek Lisans Tezi, Atatürk Üniversitesi, Arkeoloji ve Sanat Tarihi ABD, Erzurum 1996. 
368

Kurtz - Boardman 1971

Liddell - Scott 1999

LGPN V.A

LGPN V.B

Malzbender et al. 2000

Malzbender et al. 2001

Mason 1974

Money 1990

Mudge et. al. 2005

Mudge et al. 2006

Mudge et al. 2012

Ormerod-Robinson 1914

Özer 2013

Öztürk 2003

Öztürk 2006

Özüdoğru 2013

Palma et al. 2012
Nihal TÜNER ÖNEN - Betül GÜREL - Aykan AKÇAY

D. C. Kurtz - J. Boardman, Greek Brial Customs. Cornel University Press. New York 1971.

H. G. Liddell - R. Scott, A Greek-English Lexicon. Oxford $1999^{7}$.

P. M. Fraser - E. Matthews, A Lexicon of Greek Personal Names, Volume V.A: Coastal Asia Minor: Pontos to lonia. Oxford 2010.

J. S. Balzat - R. W. V. Catling - É. Chiricat - F. Marchand, A Lexicon of Greek Personal Names, Volume V.B: Coastal Asia Minor: Caria to Cilicia. Oxford 2014.

T. Malzbender, D. Gelb, H. Wolters, B. Zuckerman (2000). "Enhancement of Shape Perception by Surface Reflectance Transformation". Technical Report, Hewlett-Packard Laboratories 2000.

T. Malzbender, D. Gelb - H. Wolters. "Polynomial Texture Maps". $28^{\text {th }}$ Annual Conference on Computer Graphics and Interactive Techniques (SIGGRAPH'01). New York (2001) 519-528. Doi: 10.1145/ 383259.383320.

H. J. Mason, Greek Terms for Roman Institutions: A Lexicon and Analysis. Toronto 1974

D. K. Money, "Lions of the Mountains: the Sarcophagi of Balboura". Anatolian Studies XL (1990) 29-54.

M. Mudge, J. P. Voutaz, C. Schroer, M. Lum. "Reflection Transformation Imaging and Virtual Representations of Coins from the Hospice of the Grand St. Bernard". The $6^{\text {th }}$ International Symposium on Virtual Reality, Archaeology and Cultural Heritage (VAST'05) Pisa, Italy (2005) 29-39.

M. Mudge, T. Malzbender, C. Schroer - L. Marlin. "New Reflection Transformation Imaging Methods for Rock Art and Multiple-Viewpoint Display". Eds. M. Ioannides, D. Arnold, F. Niccolucci - K. Mania, The $7^{\text {th }}$ International Symposium on Virtual Reality, Archaeology and Cultural Heritage (VAST'06), Eurographics Association, Nicosia, Cyprus (2006) 195202

M. Mudge, C. Schroer, T. Noble, N. Matthews, S. Rusinkiewicz - C. TolerFranklin, "Robust and Scientifically Reliable Rock Art Documentation from Digital Photographs". Eds. J. McDonald, P. Veth, A Companion to Rock Art. Chichester, UK (2012) 644-659. Doi: 10.1002/9781118253892.ch36

H. A. Ormerod - E. S. G. Robinson, "Inscriptions from Lycia". JHS 34 (1914) 1-35.

E. Özer "Olympos Antik Kenti'nden Bir Grup Rölyefli Lahit". Ed. Mehmet Tekocak, K. Levent Zoroğlu’na Armağan. Suna - Inan Kıraç Akdeniz Medeniyetleri Araştırma Enstitüsü, Armağan Dizisi 3. Antalya 2013.

A. Öztürk, Batı Daglık Kilikia Bölgesi Kaya Mezarları. Yayımlanmamış Yüksek Lisans Tezi, Pamukkale Üniversitesi, Sosyal Bilimler Enstitüsü. Denizli 2003. H. S. Öztürk, M.Ö. II. - M.S. IV. Yüzyıllarda Likya-Pamfilya Bölgesinde Kırsal Alan Güvenliği. Yayımlanmamış Doktora Tezi, Marmara Üniversitesi, Sosyal Bilimler Enstitüsü, Eskiçağ Tarihi Bilim Dalı. İstanbul 2006.

Ş. Özüdoğru, "Arkaik Dönem'den Bir Likya Dynast Mezarı Üzerindeki 'Aslan Öldürme' Sahnesi: Anlamı Ve Kökeni Üzerine Değerlendirmeler". Anadolu 39 (2013) 69-86.

G. Palma G, E. Siotto, M. Proesmans, M. Baldassari, C. Baracchini, S. Batino, 
Pape- Benseler 1911

Petersen - v. Luschan 1889

Piquette 2014

Robert 1937

Robert 1955

Robert 1978

Schweyer 2002

SEG

Southern 2007

Sögüt 2003

Syll ${ }^{3}$

Şahin - Adak 2013

TAM

Toynbee 1996

Tüner Önen 2008

Tüner Önen 2015

Tüner Önen - Akçay 2014

Willems

Zanyi et al. 2007

Zgusta 1964
R. Scopigno "Telling The Story of Ancient Coins By Means Of Interactive RTI Images Visualization". The $40^{\text {th }}$ Computer Applications and Quantitative Methods in Archaeology (CAA2012) Southampton, UK. (2012) 26-30.

W. Pape - G. E. Benseler, Wörterbuch der griechicshen Eigennamen. Braunschweig 1911.

E. Petersen - F. v. Luschan, Reisen in Lykien, Milyas und Kibyratis. Wien 1889 (Reisen im südwestlichen Kleinasien II).

K. E. Piquette "Scribal Practice and an Early Dynastic Stone Vessel Inscription. Material and Aesthetic Implications". Eds. A. Dodson, J. Johnston - W. Monkhouse, A Good Scribe and an Exceedingly Wise Man. Studies in Honour of W. J. Tait. London (2014) 241-250.

L. Robert, Études Anatoliennes: Recherches sur les inscriptions grecques de I'Asie Mineure. Paris 1937.

L. Robert, Recueil d'épigraphie, de numismatique et d'antiquités grecques. Hellenica X. Paris 1955.

L. Robert, "Documents d'Asie Mineure". BCH 102 (1978) 395-543.

A. V. Schweyer, Les Lyciens et La Mort: Une Etude D'Historie Sociale. Paris 2002.

Supplementum Epigraphicum Graecum.

P. Southern. The Roman Army. A Social and Institutional History. Oxford University Press 2007.

B. Söğüt "Daglık Kilikia Bölgesi Mezar Nisleri”. Olba VII (2003) 239-260, Mersin. Sylloge inscriptionum graecarum, Vol 4. Leipzig 1915-1924.

S. Şahin-M. Adak, Stadiasmus Patarensis. Itinera Romana Provinciae Lyciae Likya Eyaleti Roma Yolları. İstanbul 2013.

Tituli Asiae Minoris. Wien.

J. M. C. Toynbee, Death and Burial in The Roman World. London 1996.

N. Tüner Önen, Phaselis Antik Kenti ve Teritoryumu. Yayımlanmamış Doktora Tezi, Akdeniz Üniversitesi. Antalya 2008.

N. Tüner Önen, "Annäherungen zur Geschichte der Stadt Phaselis auf onomastischer Grundlage: Ein Studium der Namen aus Phaselis und ihrem Territorium". Phaselis I (2015) 3-67.

N. Tüner-Önen, A. Akçay, "Phaselis Kentinin Su Teminine İlişkin Gözlemler ve Dijital Epigrafi Çalışmaları”. MJH IV/2 (2014) 279-292. Doi: 10.13114/ MJH.201428446

G. Willems, F. Verbiest, W.Moreau, H.Hameeuw, K. van Lerberghe, L. van Gool. "Easy and Cost-Effective Cuneiform Digitizing". Eds. M. Mudge, N. Ryan - R. Scopigno, The $6^{\text {th }}$ International Symposium on Virtual Reality, Archaeology and Cultural Heritage (VAST'05) (2005) 73-80. Pisa, Italy.

Zányi E., Schroer C., Mudge M. - Chalmers A. "Lighting and Byzantine Glass Tesserae". EVA London Conference: Electronic Information, the Visual Arts and Beyond.) London 2007.

L. Zgusta, Kleinasiatische Personennamen. Prag 1964. 